IZA DP No. 5677

Labor Disputes and Labor Flows

Henri Fraisse

Francis Kramarz

Corinne Prost

April 2011 


\title{
Labor Disputes and Labor Flows
}

\author{
Henri Fraisse \\ Banque de France \\ and IZA \\ Francis Kramarz \\ CREST-INSEE, \\ CEPR and IZA \\ Corinne Prost \\ CREST-INSEE
}
April 2011
IZA
P.O. Box 7240
53072 Bonn
Germany

Discussion Paper No. 5677

Phone: +49-228-3894-0

Fax: +49-228-3894-180

E-mail: iza@iza.org

\begin{abstract}
Any opinions expressed here are those of the author(s) and not those of IZA. Research published in this series may include views on policy, but the institute itself takes no institutional policy positions.

The Institute for the Study of Labor (IZA) in Bonn is a local and virtual international research center and a place of communication between science, politics and business. IZA is an independent nonprofit organization supported by Deutsche Post Foundation. The center is associated with the University of Bonn and offers a stimulating research environment through its international network, workshops and conferences, data service, project support, research visits and doctoral program. IZA engages in (i) original and internationally competitive research in all fields of labor economics, (ii) development of policy concepts, and (iii) dissemination of research results and concepts to the interested public.
\end{abstract}

IZA Discussion Papers often represent preliminary work and are circulated to encourage discussion. Citation of such a paper should account for its provisional character. A revised version may be available directly from the author. 


\section{ABSTRACT}

\section{Labor Disputes and Labor Flows ${ }^{*}$}

About one in four workers challenges her dismissal in front of a labor court in France. Using a data set of individual labor disputes brought to French courts over the years 1996 to 2003, we examine the impact of labor court activity on labor market flows. First, we present a simple theoretical model showing the links between judicial costs and judicial case outcomes. Second, we exploit our model as well as the French institutional setting to generate instruments for these endogenous outcomes. In particular, we use shocks in the supply of lawyers who resettle close to their university of origin. Using these instruments, we show that labor court decisions have a causal effect on labor flows. More trials and more cases won by the workers cause more job destructions. More settlements, higher filing rates, and a larger fraction of workers represented by a lawyer dampen job destructions. Various robustness checks confirm these findings.

JEL Classification: J32, J53, J63, K31

Keywords: employment protection legislation, labor flows, labor judges, unfair dismissal, France

Corresponding author:

Henri Fraisse

Banque de France

31 Rue Croix-des-Petits Champs

75001 Paris

France

E-mail: hf42@cornell.edu

\footnotetext{
* We are grateful to John Abowd, David Autor, Jed DeVaro, Marc Ferracci, Joop Hartog, Larry Kahn, and Iona Marinescu for useful comments. We also thank seminar participants at the Banque de France, Crest, MIT, New York University, University of Chicago, Yale University as well as participants at the EDHEC-GAIN-ADRES conference, IZA summer school, EALE conference, CPB workshop, and ESSLE conference. The opinions expressed here are the authors' own and do not necessarily reflect the views of the Banque de France and Insee.
} 


\section{Introduction}

Following the seminal paper by Lazear (1990), the effects of employment protection legislation (EPL, hereafter) on labor markets have been extensively examined through cross-country analyses, using indicators supposed to capture the national strictness of EPL (see Freeman, 2005, for a critical review). A recent strand of literature assesses the impact of EPL within countries, using changes in the legislation. This strategy typically involves measuring the impact of a change in legislation targeted to a specific category within a whole country or -- in the case of the US -- the impact of the differential timing in the introduction of a new EPL across different states. Autor, Donohue, and Schwab (2006) take advantage of the between-state variation in the timing of the introduction of labor laws in the US; they find that the "implied-contract" exception law, meaning that the employer implicitly promised not to terminate a worker without good cause, has reduced state employment rate by 0.8 to $1.7 \%$. Boeri and Jimeno (2005), using the 1990s tightening of the Italian regulation for firms with less than 15 employees, find that the threshold does matter in conditioning layoff and hiring probabilities but find no significant impact on employment growth. Bauer, Bender and Bonin (2007) find no effect of the change in the German EPL exemption for small firms on worker turnover. Martins (2009) reaches the same conclusion using Portuguese matched employer-employee data. Marinescu (2009) finds that the 1999 change in employment seniority before being eligible to go to court in the UK - it went from 200 days to 100 - had a substantial impact on the firing hazard of the workers with one to two years of tenure. Virtually all of these studies use some form of discontinuity across time and space in laws. ${ }^{1}$ Because there is no such variation in France where most legislation is set nationally (labor laws, minimum wages...), such strategies are hard to translate into the French context.

This strand of research suffers from downsides other than its lack of applicability in France. First, these studies do not provide information concerning the degree of enforcement of labor regulations. To which extent these regulations were used by workers to defend their own interests? Are these regulations actually binding for employers? For instance, in the case of the US, even if judicial breaches to the employment-at-will doctrine have been judged by some state courts, we have little evidence on the extent to which they are used or even known by the workers. Therefore, we do not know if they act as a credible threat to the employment-at-will policy. The state of California recognized the application of the covenant of good faith and fair dealing to employment relationships in 1980. In March and April 1986, about 100 cases were filed in Los Angeles which implies an approximate number of 1,000 for the entire year in the entire state ${ }^{2}$ (hence, about 80 cases per million

\footnotetext{
${ }^{1}$ This is true of most of the other studies not cited in this paragraph.

${ }^{2}$ In 1986, civil case filings in Los Angeles represented about 60\% of all civil activity in the state of California.
} 
workers). ${ }^{3}$ In comparison, for France, with a population and GDP close to those of California, 160,000 cases take place in any given year. Of course, one could argue that the law can act on the employer in a pre-emptive way but, to capture any effect in the data, this impact should be very strong (or conversely the impact on employment of labor courts should be extreme in France). Second, labor laws are subject to court interpretation and tend to vary over time and space. As pointed out by The OECD 2004 Employment Outlook, even if an employer may be sanctioned in case of non-respect of EPL, "these provisions are subject to court interpretation and this may constitute a major (but often hidden) source of variation in EPL strictness both across countries and over time”.

Therefore, opening the black box of the labor courts seems a promising path, in particular in the case of France with little other source of meaningful variation, as mentioned above. Enforcement of the law may indeed matter more than its content (see for example Bhattacharya and Daouk, 2002 who find that insider trading laws decrease the cost of equity only when a case has been prosecuted). Yet, empirically, problems of endogeneity abound: court interpretation with the ensuing impact might not be exogenous as market conditions are likely to have an impact on the leniency of the courts, the introduction of new laws, or workers' propensity to go to court. Ichino, Polo and Rettore (2003), using micro data on labor court cases, focus on this institutional endogeneity of EPL enforcement. Studying the case of an Italian bank with roughly 20,000 employees among which 409 workers were fired and 86 of them went to trial over more than 20 years, they show that a higher unemployment rate increases worker's probability of winning her case. In contrast, Marinescu (2008) - using data from a 1992 survey of Employment Tribunal Applications in Great Britain - finds that a higher unemployment rate leads to more decisions against the workers, in particular when they were already re-employed.

In this paper, we make the best of the constraints induced by the French system by using labor courts to analyze the judicial process and its impact on the labor market. The French EPL system -characterized by large separation costs, high workers coverage by collective bargaining agreements, powerful unions -- is usually considered by international organizations as one of the strictest in the developed world. It also produces every year a large amount of legal procedures related to individual labor disputes (roughly 160,000 new cases every year, as we will see). About 1 in 4 dismissed workers indeed challenges her dismissal in front of a labor court. These procedures are complex, costly, and can last for months. It is these legal procedures that we analyze in this paper. We examine their impact on employment flows. However, in contrast with virtually all of the literature, we do not focus on legislation changes but on the judicial process itself. We measure case outcomes - trial rates, conciliation rates... -- directly using all cases that took place in France between 1996 and 2003. We relate these outcomes to the legal environment of each French local jurisdiction. We then try to

\footnotetext{
${ }^{3}$ These figures are taken from Dertouzos (1988). Notice though that arbitrators operate in the US before intervention of the courts, but their efforts are not recorded in any registry (a point made by John Abowd).
} 
understand how these legal outcomes affect job creations and job destructions within the jurisdiction of each court, using flows measured at those establishments that are within the court jurisdiction.

To illustrate the links between judicial activity and labor dynamics, we build a simple model relating firing costs to judicial activities of the courts. The firing costs have a direct effect on the probabilities of hiring and firing for the firms (see for instance Bentolila and Bertola, 1990 for the theory and the papers cited above for the empirics).

We use our model to look for potential instruments that could be applied in our empirical analysis. We also use it to understand how indicators of judicial activity are linked to separations costs. The complexity of this link comes from composition effects of those cases that go to court. These composition effects have direct consequences on final separation costs: for instance, if only "expensive" cases come to court, on one side the firm economizes on the extensive margin (less cases) but pays more on the intensive margin (more expensive). Therefore, measured case outcomes do not have a simple and univocal interpretation in terms of separation costs: a positive shock on the number of trials may imply larger separation costs if the extensive margin is the main driving factor of the costs, but it may also entail lower separation costs when those cases that go to court become "cheaper”. This result does not only apply to labor courts but also to divorce or more generally to any legislation that alters the decisions of workers, couples, firms when they contract, sue, or indeed go to court. $^{4}$

On the empirical side, our contribution is fourfold. First, we consider measures of judicial case outcomes directly coming from legislation enforcement with variation across space and time. In France, workers can contest the conditions of a firing by filing a case to one of the 264 local labor courts. We use information collected by the French Ministry of Justice on all cases that were filed over the 1996-2004 period to compute, for each geographical jurisdiction and each year, various indicators characterizing the enforcement of the labor laws: the percentage of dismissed workers who litigate in employment tribunals, the fraction of cases leading to a conciliation between parties, to a trial, resulting in a worker's victory, or the fraction of cases in which workers were legally represented. We match these local indicators with local measures of the legal environment (lawyers, labor court judges, and administrative staff in the tribunal) as well as local measures of job flows à la Davis and Haltiwanger (1992).

Second, as we work at the level of France, a country in which many institutions are centralized and do not vary across the French territory (minimum wage, unemployment benefits, wage bargaining...), we

\footnotetext{
${ }^{4}$ This has not escaped some analysts; see for instance Stevenson (2007) on legislation and divorce rates.
} 
are able to "control" for most of the French labor market institutions. Third, thanks to the precise French institutional setting and those local measures of legal environment, we use an instrumental variable strategy to correct for the endogeneity from which estimation of the relation between economic conditions, including labor flows, and application of the labor laws might suffer. These instruments rely on the location of universities training French lawyers, irrespective of their legal specialization as well as on administrative features presiding over the allocation of judges and judicial clerks across French territory. All these features are shown to be disconnected from local business conditions. Then, we measure the effect of various case outcomes on employment flows. Fourth, as noted above, because labor laws in France do not vary across local areas (see however Chemin and Wasmer, 2009, on the noticeable exception of the working time reduction laws in one French region, Alsace-Moselle and the one presented in this paper as a robustness check), a difference in difference approach on changes in the legislation is difficult to implement in a French setting. Our local enforcement indicators approach (paired with the appropriate instruments) offers one of the few credible substitutes to this classic identification strategy, in addition one that has never been used, to analyze France. $^{5}$

As in all of the empirical papers we are aware of, our paper focuses on the impact of labor regulations on labor market characteristics and leave aside the welfare gains from job stability which must be taken into account for policy recommendations. ${ }^{6}$ However, and in contrast with the existing empirical literature, our labor court outcomes capture some dimensions of the quality of labor relations which according to Blanchard and Philippon (2004) or Algan and Cahuc (2009) are related to the evolution of labor market conditions.

To briefly summarize our results, we show that labor court decisions have a causal effect on labor flows. More trials and more cases won by the workers cause more job destructions. More settlements, higher filing rates, and a larger fraction of workers represented by a lawyer dampen job destructions.

Section 2 describes the French labor courts institutional setting. Section 3 presents a simple theoretical model relating the case outcomes to firing costs. Section 4 describes our data sets and the instrumental variables. Section 5 explains our empirical methodology to capture causal effects and presents our regression results on labor flows. We briefly conclude.

\footnotetext{
${ }^{5}$ See however Bertrand and Kramarz (2002) who use political instruments to capture the impact of zoning regulations on retail employment.

${ }^{6}$ See Bertola (2004) for a theoretical model considering risk-averse workers and potential positive effect of EPL on welfare.
} 


\section{Labor Courts in France: the Institutional Setting}

\subsection{French Firing Laws}

Under the current French law, separations are classified in two types: dismissals for a personal motive and dismissals for an economic motive. Economic dismissals are redundancies due to a slowdown in the business activity. Individual dismissals (personal motive) occur when the firm's decision to fire a worker is triggered by a grave misconduct of the worker or an insufficient level of competencies. In France as in many European countries, an economic dismissal entails a more complicated and time consuming process as well as the payment of large severance fees. On the contrary, a dismissal for misconduct is a faster process - if not challenged by the worker or if confirmed by the labor court. Thus the dismissal for "just" cause implies a lower firing cost than a redundancy. When fired, a French worker might sue the firm. ${ }^{7}$ Since a bill passed in 1973, every individual dismissal must be justified by a "real and serious cause" and the firm has the burden of proof. Without delving deep into 30 years of jurisprudence that have made this concept simultaneously blurred and precise, "real" means that the wrongdoing justifying the dismissal must be objectively defined, accurate, and in line with the mandatory firing notification letter. For example, being ten minutes late does not mean being seventy minutes late; a lack of performance or a lack of trust is not considered "real” if it is not objectively measured. The cause is considered as "serious" only if it is related to the professional activity of the worker and if it makes the labor relation impossible to continue. There are various degrees of "seriousness". Some lead to "grave misconduct" (for example brawl or thievery) which allows the employer to fully deprive the worker of severance payment (in this case, the employee may lose her unemployment benefits).

\subsection{French Labor Courts}

The French labor justice is mainly dispensed by the "Prud'hommes" which is the relevant jurisdiction to every labor dispute arising at the individual level in France. In the 90's, 264 Prud'hommes jurisdictions were spread all over metropolitan France, a tribunal being at most within a radius of 30 miles from any establishment.

There are several sections in each Prud'hommes. As the legislators wanted to take into account industry characteristics of the cases brought to court, each Prud'homme is divided into 4 sections according to the main activity of the firm: Agriculture, Retail Trade, Manufacturing, and Other Activities (mainly Services). A fifth section is dedicated to cases involving "managers, engineers, and professionals" irrespective of the activity of the firm.

\footnotetext{
${ }^{7}$ The worker has to leave the firm when fired, even if she sues the employer. In the end, the court may reinstate the worker within the former employing firm, but this is extremely rare.
} 
The judges in the Prud'hommes are not professional judges and are seen by some as performing a public duty. Each labor court comprises judges representing employers and judges representing employees in equal number. These judges are elected every five years within lists established by worker unions and employer federations. On the employee side, the electoral body includes all private sector workers with a labor contract.

Prud'hommes are supposedly not very formal and should be seen as conciliation boards. They were designed to foster agreements rather than trials. Therefore a first and mandatory step in each trial is a conciliation audience where plaintiffs and defenders explain their grievance and judges try to push for an agreement. ${ }^{8}$ If they do not, the case is judged. If, in the end, an equal number of judges decide in favor of a worker and against her, there is a tie ("solution de départage"). In this case, a single professional judge decides the outcome of the trial. ${ }^{9}$

A majority of plaintiffs are represented by a lawyer. ${ }^{10}$ The plaintiff or the defender can appeal the decision of the court if the stake is larger than a given threshold (about 5,000 euros in 2006). It is worth noting that $60 \%$ of the decisions were appealed in 2004 . Among them, $55 \%$ of these appeals did not overrule the Prud'hommes' decision, 30\% confirmed it "partially". ${ }^{11}$

For any given case filed in a labor court, the range of outcomes is wide. A case can lead to a full tribunal hearing and be lost or won. It can be classified as null and void if the plaintiff has not shown due diligence in the conduct of her case. The case can also be crossed out. Finally, a case can either be conciliated during the conciliation step or outside the tribunal with a formal agreement sent to the court.

The motives for suing are multiple. The nullification of a dismissal is asked in the majority of cases (58\%). ${ }^{12} 21 \%$ of plaintiffs ask for some compensation that was not paid by their former employer whereas $9 \%$ of plaintiffs do not agree with the level of their severance payment. In this paper, we do not distinguish between these different motives.

\footnotetext{
${ }^{8}$ It is worth noting that to this respect, the French setting is close to almost every OECD country, where courts usually attempt to reach a compromise solution at the start of formal legal proceedings (see Venn, 2009).

9 Moreover, in case of an emergency, a summary judgment can be made. However, such judgments are only temporary and might be overruled afterwards. In this paper, we do not consider these summary judgments.

${ }^{10}$ Firms are also often represented by a lawyer.

${ }^{11}$ Munoz-Perez and Serverin (2006). Unfortunately, current available data sets do not allow us to track the cases across the levels of jurisdictions; whether the decision is appealed by the worker or the firm is unknown.

${ }^{12}$ In the very vast majority of the cases won by the workers, they are not reinstated but receive a compensatory award.
} 


\section{Judicial Activity and Firing Costs: a Simple Theoretical Model}

We develop a simple analytical model determining the relationships between judicial activities and firing costs, taking specifically into account the conciliation step in the judicial process. Our intention is not to break new theoretical ground but rather to focus ideas. We do not study here the theoretical impact of firing costs on labor market variables. This has been extensively examined elsewhere. Larger firing costs should entail slower and smaller adjustments than separations inducing no costs (see for instance Bentolila and Bertola, 1990 and Bertola, 1992).

To illustrate how firing costs are related to case outcomes, we depart from the traditional model of litigation proposed by Priest and Klein (1984) or Bebchuk (1984) or more recently Card and McCall (2009) to run a cost-benefit analysis similar to the one proposed by Flanagan (1989) for disputes related to the compliance to the National Labor Relations Act in the US. For simplicity, the model that we describe below has no uncertainty, no asymmetric information that would explain why trials take place; everything is known and predictable; we will come back later on this topic and discuss how our results are affected by asymmetric information.

In our analysis, the employer can deliberately choose to pay a minimal firing cost with the risk to be sued by the worker; or to pay a larger amount, which corresponds to the payment a plaintiff would accept in order to give up any further possibility of lawsuit. Important to note here that this last sum is not negotiated between the firm and the worker, but is directly coming from legal precedents (jurisprudence). In France, it amounts to one to two years of earnings. Another way of understanding the model is as follows: a firm chooses to dismiss the worker either for a personal motive, paying a small severance payment, or to dismiss the worker for an economic motive (redundancy) with larger severance payments. ${ }^{13}$ Our hypothesis, then, is that when firms pay the severance payment corresponding to a redundancy, the workers never choose to sue the firm (indeed, 97.5\% cases in our data come from dismissals for personal motive rather than redundancies). When the worker goes to court after a dismissal, the firm has to prove that the case is a legitimate dismissal for personal motive rather than a redundancy.

In the case of a dismissal for personal motive, the firm incurs a minimum severance payment $\left(c_{m}\right)$ if the dismissal remains unchallenged by the worker. This payment $c_{m}$ is lower than the maximum severance payment $c_{M}$, which leads the worker not to sue the firm. Yet the firm has to take into account the facts that the worker can file a suit ( $p_{f}=1$ if he does, $p_{f}=0$ otherwise) and that he can then end the case with a formal agreement in front of the judge ( $p_{c}=1$ if he does, $p_{c}=0$ otherwise). The firm also knows the probability that the worker wins if the trial occurs, $p_{w}$. We assume that during the

\footnotetext{
${ }^{13}$ For an empirical illustration of a trade-off between two litigation processes, see Oyer and Schaefer (2000).
} 
conciliation step, the judge tries to reach an agreement using an "intermediary" severance payment $c_{c}$, given by the jurisprudence, always lower than $c_{M}$. Note that in order to simply introduce the coexistence of a conciliation stage and a trial stage we consider $c_{c}$ to be constant. The firm cannot increase $c_{c}$ in order to avoid the trial.

Uncertainty of the entire process is summarized through $p_{w}$. The firm and the employee share this value. In this cost-benefit analysis, we assume that the quality of each case is known by both parties and is related to observed characteristics of the workers and of the firms. ${ }^{14}$ For instance, union or personnel delegates or pregnant women are very well protected by the law, and the judges are very strict against dismissals of such individuals. Several past statements of judgments also show that judges demand more stringent evidence when a firm has had large positive profits in the years preceding the trial. ${ }^{15}$

At this point, the model has no uncertainty, no asymmetric information that explains why trials take place. Theoretically, firms and workers should agree on a payment in order to avoid the litigation costs. Two features could be added to the model in order to explain why firms and workers go first to the Prud'hommes and then, if ever, to trial. First, costs for reaching an agreement without any mediator like the judge could be larger than the costs at the conciliation stage. This seems plausible since the Prud'hommes institution is seen as a public good and the conciliation stage is essentially free. Second, in line with the literature in which trial is an equilibrium outcome, we can assume that the worker and the firm have different and irreconcilable expectations on the outcome of the trial. This assumption would lead to a "contract zone" where a settlement amount can be found (see Bebchuk, 1984). When the expectations are not in the contract zone, the trial takes place; else an agreement can be found at the conciliation stage. Because there is a need to model expectations, computations become much less tractable. The model loses its simplicity without gaining much insight for our purpose. In addition, as underlined by Spier (2007) such a model does not fully solve the litigation puzzle since the conciliation stage should help the expectations to narrow. Again, it is possible to assume two stages of narrowing expectations, one leading to conciliation, one to the trial. ${ }^{16}$ From this discussion, it is however interesting to note that workers employed in large firms are virtually absent from the Prud'hommes. In line with the above discussion, the various probabilities should be better known by the human resources management and union delegates that are always present in the larger firms. Hence, they should escape trials and easily agree on separation payments, as is observed. In small firms, conflicts become often personal and difficult to solve without the help of a neutral third party, a role apparently played by the Prud'hommes.

\footnotetext{
${ }^{14}$ As mentioned above, this assumption is discussed below.

${ }^{15}$ Unfortunately, the data do not contain a firm identifier. Hence, it is not possible to directly relate firm and worker behavior.

${ }^{16}$ Computations not included in the Appendix are available from the authors.
} 
Now, let us go back to our model. If choosing $c_{m}$ the expected firing cost for the firm is:

$$
E(c)=p_{f}\left\{p_{c}\left(c_{c}+l_{c}\right)+\left(1-p_{c}\right)\left[p_{w}\left(c_{m}+F\right)+\left(1-p_{w}\right) c_{m}+l_{t}\right]\right\}+\left(1-p_{f}\right) c_{m}
$$

where $F$ is a compensatory award for the worker, $l_{c}$ is the firm's litigation cost when the parties reach an agreement at the conciliation stage, and $l_{t}$ is the firm's litigation cost when the parties go to trial. Otherwise, the severance payment is $c_{M}$.

As for the worker, if the firm chooses $c_{m}$, the expected severance payment is:

$$
E(s)=p_{f}\left\{p_{c}\left(c_{c}-k_{c}\right)+\left(1-p_{c}\right)\left[p_{w}\left(c_{m}+F\right)+\left(1-p_{w}\right) c_{m}-k_{t}\right]\right\}+\left(1-p_{f}\right) c_{m}
$$

$k_{c}$ being the cost of litigation for the worker at the conciliation stage, $k_{t}$ being the cost at the trial stage. Otherwise, the received payment is $C_{M}$.

The parameters $p_{f}$ and $p_{c}$ result from the optimization from the firm and the worker and equal one or zero. The worker chooses to go to court or not; and in that case to accept the conciliation or not. The firm chooses to pay $c_{m}$ or $c_{M}$; and, if at the court, to accept the conciliation or not.

We define: $\overline{p_{w}}=\frac{k_{t}}{F}, \overline{\overline{p_{w}}}=\frac{c_{c}-c_{m}+k_{t}-k_{c}}{F}, p_{w}^{*}=\frac{c_{c}-c_{m}-l_{t}+l_{c}}{F}$, and $p_{w}^{* *}=\frac{c_{M}-c_{m}-l_{t}}{F}$

Under several assumptions (see Appendix), there are four equilibria, depending on the value of $p_{w}$ :

Equilibrium (1): for small probabilities $p_{w}<\overline{p_{w}}$, the firm pays $c_{m}$ and the worker does not go to court ( $p_{f}=0$ and $\left.p_{c}=0\right)$ since the firm would refuse the conciliation and the gain at trial would be negative for the worker.

Equilibrium (2): when $\overline{p_{w}}<p_{w}<\overline{\overline{p_{w}}}$, the expected gain of the worker at trial is positive. She can credibly threat the firm to go to a full hearing. Since $p^{*}{ }_{w}<\overline{p_{w}}$ the firm accepts to settle with the worker. The settlement amount is lower than the expected loss of the firm at trial but larger than the expected gain of the worker. ( $p_{f}=1$ and $\left.p_{c}=1\right)$.

Equilibrium (3): when $\overline{\overline{p_{w}}}<p_{w}<p_{w}^{* *}$, the worker is better off at the trial stage and refuses to conciliate anymore $\left(p_{f}=1\right.$ and $\left.p_{c}=0\right)$. 
Equilibrium (4): when $p_{w}>p_{w}^{* *}$, the firm pays $c_{M}$ since it would be too costly to go to court.

The firing cost, depending on the probability of winning of the case, is shown on Figure 1.

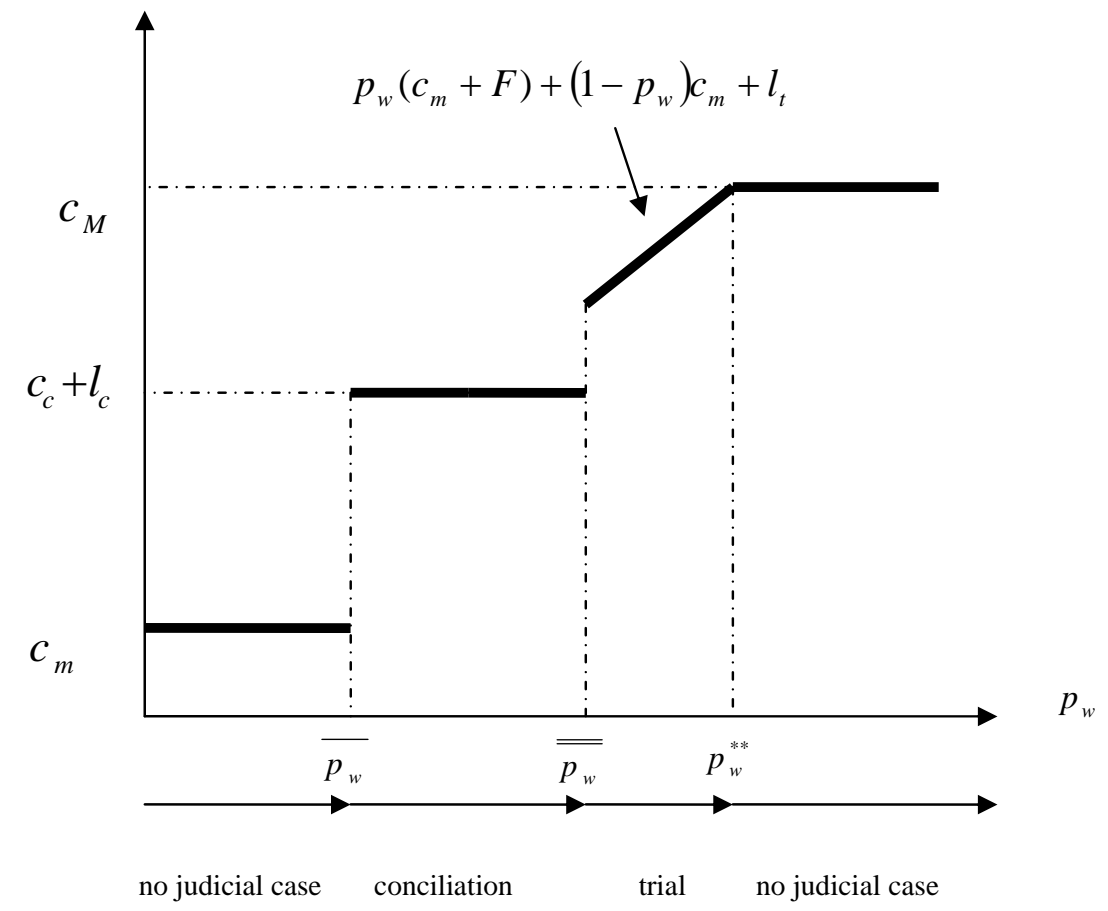

Fig. 1: Firing Cost

Discussion: We consider that firms are facing an invariant distribution of case quality. This model shows that changes in the litigation costs have intuitive impacts on the global firing costs; yet the results on the case outcomes are ambiguous. For instance, an increase in the firm's litigation cost at trial $l_{t}$ implies a decrease in $p_{w}^{* *}$ (see Figure 2). The firm will be more likely to fire high probability workers with an economic motive to avoid lawsuits. It will also increase the relative cost of a trial with respect to conciliation. The expected firm's cost at trial will rise. All these changes lead to an increase in the firing cost, a decrease in the trial and filing rates. Hence, a smaller number of trials and filing cases appear to be associated (in some cases at least) with more EPL. 


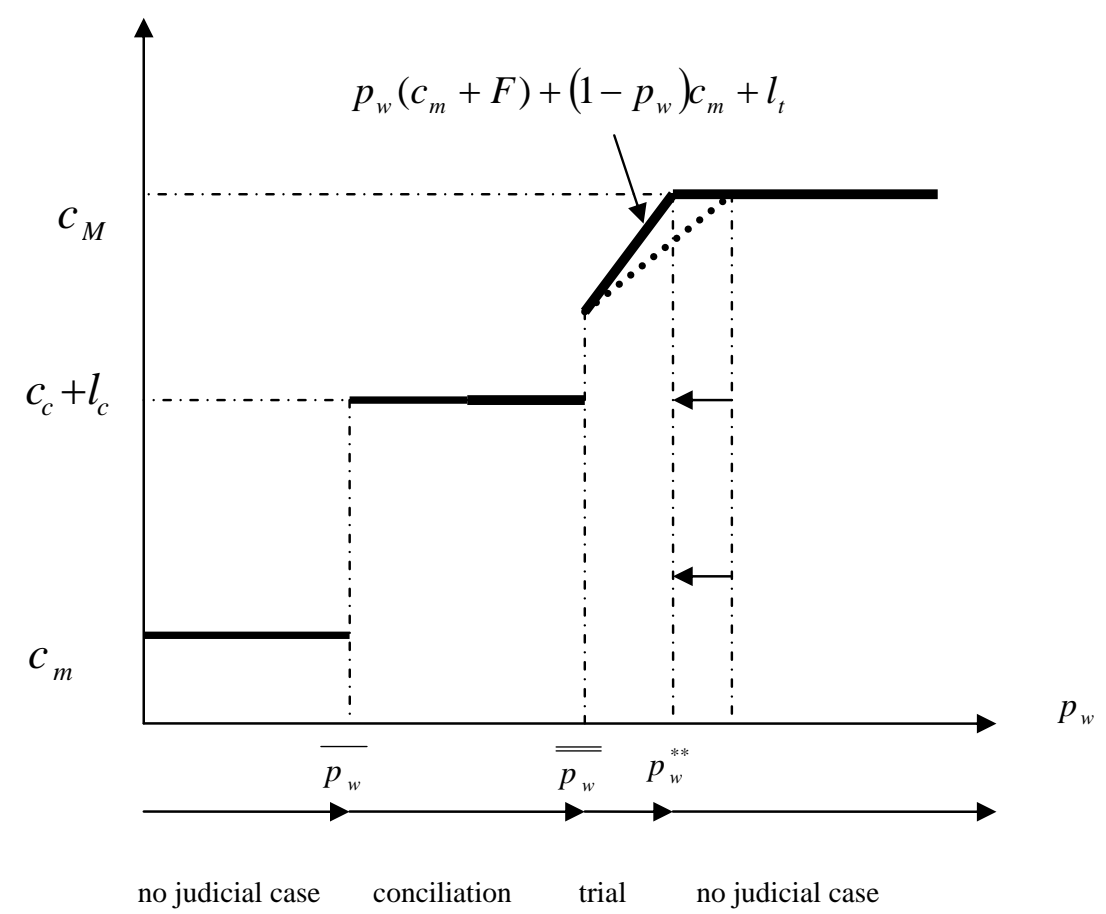

Fig. 2: Firing Cost, Case Outcomes and an Increase in the Litigation Costs for the Firm

Let us study the following case that stands in stark contrast with the previous one (see Figure 3). An increase in workers' litigation costs $k_{t}$ will induce a decreased probability for the workers to file a case (through a higher $\overline{p_{w}}$ ) as well as more workers that prefer to conciliate (through a higher $\overline{\overline{p_{w}}}$ ). In this situation (contrasting with the previous one), a smaller number of trials is associated with lower total firing costs. In fact, our model shows that firing costs directly depend on variation in input costs; yet the link with case outcomes is ambiguous. 


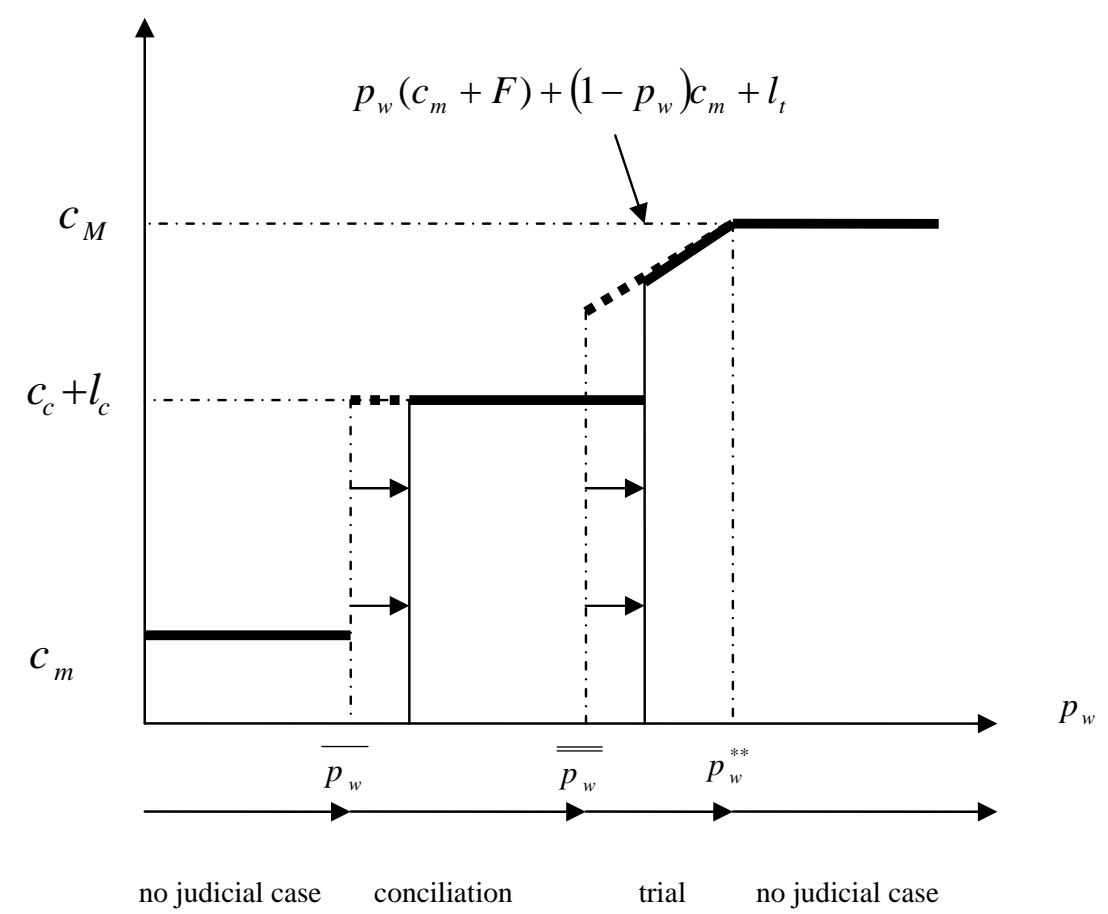

Fig. 3: Firing Cost, Case Outcomes and an Increase in the Litigation Costs for the Worker

\section{Data and Methodology}

\subsection{Judicial Cases Data}

Our data source on individual cases comes from administrative records made at the level of each geographical jurisdiction and collected by the statistical department of the French Ministry of Justice. The primary goal of these data is to monitor the activity of labor courts with an emphasis on speed of treatment. The data source is exhaustive for the period 1996 to 2003. It includes approximately 1.5 millions individual cases. ${ }^{17}$

For each case, the starting date, the ending date, the motives for dismissal, and the court decision are recorded. An average case takes approximately one year (343 days) with a standard deviation of 9 months. ${ }^{18}$ For each case, we know the legal representation chosen by the firm and the plaintiff. Few characteristics of the employee-plaintiff are available: mainly gender and age. As for firms' characteristics, we know the industry, the size (more or less than 10 workers), and the Prud'hommes

\footnotetext{
${ }^{17}$ We will not consider the $2 \%$ of cases involving employers as plaintiffs.

${ }^{18}$ Because we use jurisdiction-level information for our analysis, rather than case-level information, our Tables will report jurisdiction-year statistics. All case-level statistics are available from the authors on request.
} 
section of the employing firm (i.e. the industry broadly defined). The size of the firm has to be known by labor court judges because labor laws differ for small firms; more specifically, they are less stringent and try to ease the financial costs of firing that could hurt them irreversibly. Small firms are overrepresented with $56 \%$ of the filed cases whereas they comprise $25 \%$ of the labor force.

These data on individual cases are used to compute several aggregate measures of the cases examined in each jurisdiction-year pair. The first indicator relates to litigiousness: the filing rate, number of cases over the number of dismissed persons. ${ }^{19}$ The second indicator relates to representation: the worker lawyer rate, number of cases where the worker is represented by a lawyer over the number of cases. The three other indicators describe the main outcomes of the cases, which are: the worker and the firm manage to conciliate, or they go to trial, and in that case, either the worker wins or not. Thus we build three indicators: the conciliation rate, number of cases conciliated or having led to an agreement over the number of cases; the trial rate, number of cases having reached trial over the number of cases; ${ }^{20}$ the worker winning rate, number of cases having led to a victory for the worker over the number of cases (see Table 1 for the definition of the indicators).

Admittedly starting from a high base, we do not observe in France a strong increase in the number of cases brought to the labor courts over our period; during this period, no change were made to the labor laws. In absolute terms, the number of filed cases increased by 10\% over the 1990 to 2004 period. The number of cases treated by labor courts appears to be stable over the period, in stark contrast with what happened in some countries such as the UK where a sharp increase took place (see Figure 4 and Burgess, Popper and Wilson, 2001). It is important to note that the percentage of filed cases among the dismissed persons is large (mean of $22 \%$, see Table 2). Almost one dismissal over four ends at the labor court.

Despite the conciliation step which is mandatory, and promotes a quick and costless resolution of the cases, about $60 \%$ of cases end by a trial, among which $75 \%$ lead to a worker's victory (see Table 2 ). Of all filed cases, only $20 \%$ end at the conciliation stage, or lead to an agreement notified to the court, or to a withdrawal on the worker's side. In comparison with what is observed in a country such as the UK, almost half of the workers are represented by a lawyer despite other available means of representation.

\footnotetext{
${ }^{19}$ No exhaustive statistics give the number of dismissed persons in France; we are thus obliged to have a proxy through the number of registered unemployed who declare being unemployed because of a dismissal. These figures come from a data set compiling the unemployed registered at the national employment service (ANPE at this time) in each city, distinguishing the reasons for being unemployed (dismissal, entry into the labor force, end of temporary contract...). As for labor flows (see below), we aggregate these data at the jurisdiction level.

${ }^{20}$ Because cases can also be dropped, the sum of the conciliation and of the trial rates is smaller than one.
} 
All indicators of judicial activity display a very strong variance over time and across jurisdictions. Our model can help us understanding two main sources of variability: business cycle and litigation costs. Section 4.3 will discuss the links between the business cycle and the judicial activity, which are a source of endogeneity. Then we will explain that institutional variability in the number of judges, lawyers and staff, entail different litigation costs at the jurisdiction level. This will give us our instruments.

\subsection{Labor Flows Data}

Local employment flows at the establishment level are computed from the SIRENE files, maintained at the French statistical institute (INSEE). These files give the precise location (city) for each establishment. We compute a set of Davis and Haltiwanger (1992) indicators over the 1996-2004 period: job creation, job destruction, and net job creation rates. Job creation is positive for an expanding or new business, and null for other establishments. On the opposite, job destruction is positive for a shrinking or exiting business, and null for others.

These measures are aggregated at the jurisdiction level, using a 1999 correspondence between cities and jurisdictions provided by the Ministry of Justice. The rates of job creations and job destructions from year $t$ to year $t+1$ are computed relative to average employment in the two years. In comparison with cross-country analyses, these indicators also show a high heterogeneity across periods and across the 264 geographical jurisdictions. The job creation rate and the job destruction rate evolve around an average of $16 \%$; thus the mean of the net job creation rate is zero (see Table 2).

To measure local unemployment, we use the number of unemployed as registered at the public employment office (ANPE) for each city as well as the city labor force as measured at the 1999 Census. Unfortunately, there is no data set giving us, at the local level of the city, the size of the temporary help service industry. Hence, we cannot perform an analysis as done in Autor (2003). However, in contrast with other European countries (such as Spain), the fraction of temporary workers in French total private employment is low (about 2.5\% in 2009).

\subsection{Instrumental Variables: Discussion and First Stage}

We want to assess the causal effect of our indicators describing labor disputes on labor flows. Yet the judicial activity is likely to be endogenous. Our model can be used to discuss the endogeneity problems that we will face when estimating the relations between case outcomes and labor market characteristics. For instance, an adverse shock on the labor market conditions can affect case 
outcomes. First, according to the legislator, $F$ compensates the worker for past and future potential wage losses, in particular by taking into account the difficulty of finding a new and comparable job. The magnitude of $F$ is therefore likely to be countercyclical. ${ }^{21}$ An economic downturn pushes $\overline{p_{w}}$, $\overline{\overline{p_{w}}}$, and $p_{w}^{* *}$ downwards which results, other things being equal, in higher firing costs. Moreover, if workers exert more effort on the job during a downturn (with an efficiency wage story in mind), the overall distribution of $p_{w}$ will shift upwards. Third, economic conditions might also alter the overall distribution of $p_{w}$ through judges' behavior. Judges showing a pro-worker bias when labor market conditions deteriorate increase the firing costs faced by the firms (see Ichino et al., 2003).

Thus we need instruments which explain the average outcomes observed at the level of the jurisdiction and are exogenous to current labor market developments. We claim that the local legal environment and the institutional settings of the jurisdictions themselves both provide us with convincing potential instruments because, as our model discussed, they are related to case outcomes by affecting various payments and costs of litigation and because their variations within each jurisdiction are essentially random.

\section{a) Lawyers}

Our main instrument is the number of lawyers enrolled at the local bar - lawyers of all specialties, not only those specializing in labor disputes, a small fraction of the total -- scaled by total employment of the jurisdiction ("lawyer density" hereafter). In France, each lawyer has to get licensed and registered at the local Bar ("barreau") in order to be entitled to practice. We know the number of lawyers registered at each such "barreau" from 1996 to 2006. It allows us to have a local estimate of the number of lawyers (divided by total employment in the jurisdiction). As there are fewer bars in France than Prud'hommes jurisdictions (181 versus 264), we match each Prud'homme to the closest bar using shortest route distance and compute the number of lawyers available to employees depending on one single Prud'homme. Using the 1999 Census, the national average is 77 lawyers per 10,000 employees, going from a minimum of 14 (Creuse) to a maximum of 868 (Paris).

An increase in lawyer density is likely to reduce legal fees thanks to greater competition (see Siegelman and Donohue, 1995, for a similar argument). Increased lawyer density also helps to disseminate legal expertise and judicial knowledge of labor disputes among the population of workers.

\footnotetext{
${ }^{21}$ Regressions of our indicators of judicial activity on local unemployment rates show that they are strongly correlated with the cycle (see Table A.1). The cyclical behavior of collective conflicts has been extensively studied in the literature (see Harrison and Stewart, 1994, or Devereux and Hart, 2011). The evidence about individual disputes is less extensive (see however Siegelman and Donohue, 1995).
} 
It should correspond to a lower cost of litigation for the worker ( $k_{t}$ and $k_{c}$ in our model) and hence influence the judicial activity and the case outcomes. This result of our model is true even without assuming that being represented by a lawyer increases the probability of winning.

One could argue that the lawyer's choice of location depends on local economic conditions. First, labor disputes are only a small amount of the total number of civil cases $\left(11 \%\right.$ at the national level $\left.{ }^{22}\right)$. Second, in order to get a license to practice, a lawyer must enroll the local bar which jurisdiction the Prud'homme belongs to. This requirement and the building of a reputation and a clientele induce a low mobility of lawyers from one region to another. Moreover, a lawyer typically enrolled the bar the city where she studied and, hence, her location preference is likely to be unrelated to the incidence of labor disputes litigation. To see this, first note that there are only twelve law schools spread over French territory (see Figure 5). Then, observe the strong overlap between these areas where lawyers are trained and those that see the strongest increase in lawyer density over our time period (see Figure 6). Further supporting the identifying assumption that local labor market conditions are disconnected from the increase in lawyer density, lagged labor flows are found to have no predicting power on lawyer density when including jurisdiction fixed effects and year dummies (see Appendix Table A.2). Thus changes in lawyers' density within a Prud'homme should influence judicial outcomes through the cost and the efficiency of the litigation process. These changes are likely to be exogenous with respect to current labor market developments because lawyers' mobility is mostly driven by exogenous supply shocks due to lawyers' location preferences, therefore making it a plausible instrument.

\section{b) Judges and Judicial Staff}

We also consider as instruments the number of judges and staff in charge of dealing with judicial cases (scaled by the local 1999 labor force). Both categories obviously have an impact on judicial decisions as well. Judicial activity can be modeled as a production function for the case disposition. Beenstock and Haitovsky (2004) using a panel data on Israeli courts find that judges complete more cases as their caseloads grow and complete fewer cases when new judges are appointed to their court. In the case of Prud'homme, the sociological literature ${ }^{23}$ supports this result and states that facing an increasing number of cases and having to meet some productivity requirements, judges tend to be more meddlesome implying crossing out more cases for administrative reasons to speed up the process and lighten their burden. More judges or staff would imply a decreasing marginal cost of challenging the

\footnotetext{
${ }^{22}$ See available on line Info Stat justice (2005) « Une évaluation de l’activité des juridictions en 2004 » $n^{\circ} 80$.

${ }^{23}$ See Bonafé-Schmidt (1987).
} 
dismissal following Buchanan's club theory of public goods and thus increase the firing costs through a smaller $k_{t}{ }^{24}$

\section{Judges}

Prud'hommes' judges are unequally spread over the French territory. Before 1979 when the "Réforme Boulin” took place, the administrative cost of the Prud'hommes was borne by the local administration and their creation mostly depended on a bargaining process between unions, firms, and this local administration. For instance, in those years (before 1979), 6 “départements”25 out of 95 did not have a single labor court. In 1979, a legislation strongly supported by the Minister of Labor Robert Boulin transformed the financing and made it depend exclusively on central government resources. In addition, at least one labor court had to be present in every zone that also had a civil tribunal ("Tribunal de Grande Instance"). Since then, every additional change in the number of judges within a labor court or the opening of a new labor court depends on the outcome of a bargaining between the unions, the employers' federations, the local, and the national government. The process is supervised by a national agency (“Conseil national de la Prud'hommie”). This system generated strong rigidities with the consequence of essentially freezing the number of judges. This number stayed roughly the same from 1979 until 2008, with some small changes in 2002; every bargaining party preferring the status-quo. In 2008, the reform of the judicial map leading to the closing of 66 Prud'hommes out of 264 took stock of the misallocation of judges across the French territory.

The rigidities can partly be explained by the role of the unions within the Prud'hommes system. As explained before, labor courts are divided into 4 "sections" according to the industry of the firm (Agriculture, Retail Trade, Manufacturing, Services) and a fifth section for the "Cadres" (engineers, managers, and executives). Then, voting for the employees' unions and for employers' federations takes place every 5 years in order to elect judges. These elections are crucial for trade unions as they are the only way to assess unions' representativeness at the national level. ${ }^{26}$

However, the number of judges is decided by a different procedure. Over our sample period, 2 rounds of elections took place, in 1997 and in 2002. For each round, we collected from the Ministry of Labor

\footnotetext{
${ }^{24}$ In our approach, the congestion of the labor courts increases the cost of litigation which deters workers either to file or to refuse the settlement and therefore decreases the firing cost. Two recent papers by Besancenot and Vranceanu (2009) and Stähler (2008) relate labor courts to labor markets through the existence of "judicial mistakes". The congestion of the court pushes upward the number of judicial mistakes. Bad type workers - that is workers that have rightly been fired for a personal motive - have an incentive to go to court gambling on a judicial mistake. This is found under some assumptions - and contrasting with our view - to have an increasing impact on the firing costs.

${ }^{25}$ A French "département" is equivalent to an American county.

${ }^{26}$ See Andolfatto (1992) for a political analysis of these elections.
} 
the share of judges affiliated with each union as well as the number of judges by section at the jurisdiction level. The number of judges did not change between 1996 and 2001 (see Table 3). Changes took place only in 2002 (see Table 4). ${ }^{27}$ Digging into administrative archives of the French Ministry of Labor, the number of cases brought to labor courts seems to be the main apparent quantitative indicator used to decide these changes. ${ }^{28}$ But, even after the minor changes that took place in 2002, the number of judges is far from being tightly related to labor market size or court activity and seems to be the outcome of complex negotiations with little relations with labor market developments, even more so for the changes that took place between 2001 and 2002. One empirical illustration of this disconnection is given in Table A.2 where lags of labor flows are unable to predict the number of judges. Another illustration is given in Table A.3. The disconnection between labor market changes (changes in the shares of industries) and the changes in the number of judges mainly stem from the role of the CGT, the most important union in France. The CGT is traditionally well represented in manufacturing and is reluctant to accept a reduction in the number of judges allocated to the manufacturing section, even if the share of workers employed in the manufacturing industry has declined in the geographical area. To illustrate this point, we regress the changes in the number of judges that took place in 2002 on the changes in employment between 1993 and 2002 in the same industry. We clearly see that there is no significant association between these changes in manufacturing and that the service and the trade industries are both locally under-represented (both initially and in the changes). Hence, we believe that the process of allocation of judges is independent of local labor market developments and reflect "political" forces.

\section{Judicial Staff}

In the vein of our lawyer density indicator, we consider the total number of civil servants from the Ministry of Justice working at the civil court independently of the type of cases they deal with. We obtained the number of "greffiers" (clerks) employed by the Ministry of Justice attached to tribunals in the area of each "Tribunal d'instance"29, closest to the labor court ("Staff” hereafter) over the 19922004 period. "Greffiers" are civil servants in charge of all the administrative tasks, which include assisting the workers in filing their cases as well as writing the judgment terms.

The allocation of these clerks is centrally set (by the Ministry of Justice). Their allocation planned at the national level responds to budget constraints and changes in the local caseload. At stressed before,

\footnotetext{
${ }^{27}$ Hence, within Prud'hommes, the number of judges does not show a huge amount of variation. This will force us to use judges as a "secondary" instrument, mostly for robustness checks.

${ }^{28}$ In the US, the Administrative Office of the United States Court uses statistics over the average time spent by judges to handle a case of a given type to give an appraisal of judge allocation.

${ }^{29}$ As there are more "tribunal d'instance" than Prud'hommes (460 versus 264), we use again orthodromic distance for the matching.
} 
Prud'hommes' cases represent a small share of the total civil case load and their steady number across the years is unlikely to have driven massive reallocations of judicial personnel. We check again that the clerks' density cannot be predicted by lagged labor flows (see again Table A.2).

The staff densities influence the disposition of the cases through a congestion effect. Their allocation depends on institutional settings, which generate outcomes that seem largely disconnected from local economic developments and let us think that they offer the characteristics of good instruments.

Notice the variety of origins of our instruments: "staff" comes from the allocation by the central government of civil servants into local jurisdictions; “judges” are set by the institutional and political settings of the Prud'hommes; the "lawyers" instrument is related to location preferences of the lawyers.

\section{c) First Stages and Reduced-Form Regressions}

Table 5a presents the instrumental regressions (first stage) for each of our indicators of judicial activity on the full set of potential instruments, controls (year and business cycle indicators, appropriately transformed as will be described later), and jurisdiction fixed effects. The F-statistics (test of the null of the equality to zero of the selected instruments) and its associated p-value are given in the last row of the Table. When all instrumental variables are included, even though each regression has at least one significant instrument, the F-statistics are small with only one above 10, one around 8 and other values being smaller. Interestingly, the lawyer instrument is significantly different from zero in all regressions (at a level of $1 \%$ in four out of the five regressions). More precisely, lawyer density positively affect the worker lawyer rate, hence supply shocks favor the use of lawyers by workers. It also encourages filing and conciliation but negatively affect trials and workers' victory. Hence, an important supply of lawyers appears to favor the rule of law (more filings) and reinforce the negotiating role of lawyers over its trial-lawsuit role.

Table 5b presents the same first-stage regressions with our first instrument, the local supply of lawyers. Now, as was likely from Table 5a, most F-statistics are larger and close to the limit of 10, with the exception of the worker lawyer rate. Hence, lawyers will constitute our main instrument. However, we will use judges and staff for robustness checks. We do this for two reasons. First, firststage estimates presented in Table $5 c$ show that judges appear to provide a better F-statistic for the worker lawyer rate whereas lawyers and staff yield also a larger F-statistic for the conciliation rate. In addition, the option of having two instruments will allow for a test of over-identifying restrictions. Still, these results will all be compared with those obtained with the supply of lawyers as the main instrumental variable and check their robustness. 
Focusing on the effects presented in Table 5b (judicial indicators and lawyer density), we examine now whether these estimates are consistent with our model. Consider the number of lawyers and assume that an increase in the number of lawyers induces a decrease in the costs of litigation for the worker ( $k_{t}$ and $k_{c}$ ), the decrease being larger for the cost at the trial stage than at the conciliation stage. We assume that the impact on the costs of litigation for the firm is negligible.

Under such assumptions, the model shows that $\overline{p_{w}}$ decreases more than $\overline{\overline{p_{w}}}$ : more workers file a case since it is less costly, and as a proportion more end the case at the conciliation stage than at the trial stage. Finally, the firing cost increases for the firms (see Figure 7). This is consistent with the results of the first stage in Table 5b: more lawyers imply a higher filing rate, a higher conciliation rate, and a lower trial rate. It also implies a lower worker winning rate since the new workers who litigate have smaller probabilities of winning.

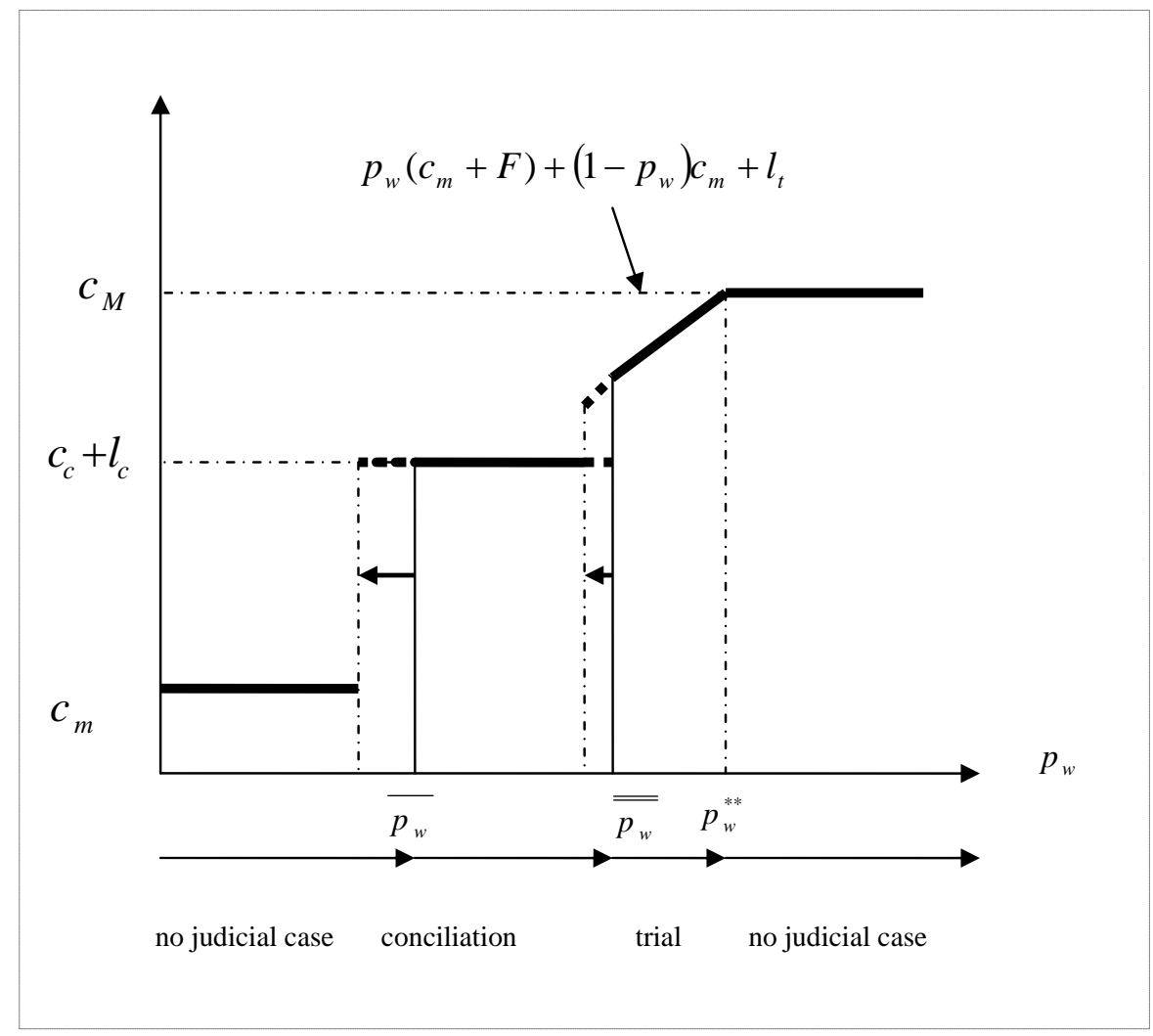

Fig. 7: Firing Cost, Case Outcomes and a Decrease in the Lawyers' Costs

To check that our instruments are well correlated with the labor flows, we estimate a set of reducedform regressions. The results are presented in Table 6. First, judge and lawyer densities have a strong negative effect on job destructions, resulting in a clear positive effect on net job creations since job 
creations are barely affected. The relations between staff density and flows are not significant (though close); still the effect is significantly different from zero (positive) on net job creations.

\section{Main Empirical Results}

Now, we can turn to our main econometric model:

$$
\text { Flows }_{p, t}=\alpha_{1} B C_{p, t}+\alpha_{2} B C_{p, t-1}+\beta \text { JudicialInd }_{p, t}+\delta_{p}+\gamma_{t}+\varepsilon_{p, t}
$$

where JudicialInd $_{p, t}$ is an indicator of judicial activity where the unit of observation is a Prud'hommes court $p$ for year $t . B C_{p, t}$ is a business cycle indicator. Our labor market variables Flows $p, t$ are the labor flows at the jurisdiction level $p$ at date $t . \delta_{p}$ is a jurisdiction fixed effect; $\gamma_{t}$ is the year indicator, and $\varepsilon_{p, t}$ is the residual. In each regression, observations are clustered at the local jurisdiction level. The jurisdiction areas display a large heterogeneity in size (measured by labor force or employment). Half of the jurisdictions account for about 80\% of the 1991 total employment. We weight our regressions by the 1999 labor force of the jurisdiction area (results are unchanged when using total employment in 1991 or some other weighting scheme).

Table 7 presents estimates of model (1) using OLS. All case outcome indicators except the filing rate are significantly correlated with job destructions, the trial rate and worker winning rate positively so whereas the worker lawyer rate and the conciliation rate negatively so. However, none of these case outcome indicators are significantly correlated with job creations. Finally, worker lawyer rate and conciliation rate are positively correlated with net job creations. The signs of the coefficients are consistent with the results of the first stage regressions and the reduced-form regressions, presented above.

To estimate the parameter $\beta$ measuring the causal impact of judicial activity on labor market flows, we adopt an instrumental approach by projecting our outcome indicators on our instruments $Z$, business cycle indicators, year dummies and local labor market fixed effects:

$$
\text { Outcome }_{p, t}=\mu_{1} B C_{p, t}+\mu_{2} B C_{p, t-1}+\lambda Z_{p, t}+\delta_{p}+\gamma_{t}+v_{p, t}
$$

We cannot use a business indicator such as the local unemployment rate, which is clearly too directly correlated to the labor flows. Local unemployment rate probably reflects unobserved economic shocks which impact simultaneously the quality of the cases brought to labor court, bias the judges in their decisions, and affect the labor flows. Thus we build an indicator of the business cycle, which takes into account the initial differences across jurisdictions and reflects the national business cycle. To do so, we instrument the measure of the local business cycle (number of unemployed registered at the 
local employment agency divided by the 1999 local labor force) by the national unemployment rate (in the spirit of Bartik, 1991 or Blanchard and Katz, 1992) using the following relation:

$$
U_{p, t}=\delta_{p}+\gamma_{t}+\mu_{p} U_{t}^{\text {aggregate }}+\eta_{p, t}
$$

Then, we use the predicted value $\hat{U}_{p, t}$ of $U_{p, t}$ by (3) to compute our exogenous measure of cycle $B C$ as $\frac{\left(\bar{U}_{p}-\hat{U}_{p, t}\right)}{\bar{U}_{p}}$ where $\bar{U}_{p}$ is the average of the predicted local unemployment rate $\hat{U}_{p, t}$.

Our IV results are given in Table 8. The structure of the Table is the following. For each case outcomes indicator we give estimates with Lawyers as the only instrument. In addition, for the two variables with relatively smaller F-statistics in Table 5.b (worker lawyer rate and conciliation rate), we present estimates with those instruments that have valid F-statistics in Table 5.c, as robustness checks. In addition, for the conciliation rate, which is the only indicator for which we use two instruments, we present a test of over-identifying restrictions.

The results of the IV procedure mostly confirm those from the OLS procedure. As usual with IV regressions, the coefficients and standard errors are both larger. The results confirm that larger conciliation rate and worker lawyer rate dampen job destructions when larger trial rate and worker winning rate increase job destructions. Interestingly, increased filing rates dampen both job creation and job destruction, with a small positive aggregate effect.

All signs are consistent with our previous analysis. To sum up, a larger lawyer density encourages workers to file their case, presumably because it is less costly for them to challenge their dismissals. Hence, more workers go to the court, with lower probabilities of winning. Proportionally, more of them find an interest in ending the case at the conciliation stage rather than at the trial stage. Thus, the conciliation rate increases, the trial rate decreases; and the worker winning rate decreases since those workers that go to the trial stage also have a lower probability of winning.

The estimated effects are large, much larger than the estimates coming from the OLS regression. This is usual when using instrumental methods that yield local estimates of the effects. A one standarddeviation increase in the conciliation rate or in the filing rate decrease the job destruction rate of 1.8 standard deviations. A one standard deviation increase in the trial rate increases the job destruction rate by 2 standard deviations. The largest effects are obtained for the worker lawyer rate and the worker winning rate: their impact is close to 4 standard deviations. The effects on net job creations are smaller: they stand between 0.6 and 1.8 standard deviations (in absolute value). 
That judicial activity has an immediate causal effect on labor flows might seem surprising. First, similar regressions using lagged (one year) indicators of judicial give similar results. Second, even though the dynamics our indicators is not easy to understand, it is important to remember that the outcomes of cases are measured in the year when the case ends. Hence, most cases have started in the year before (or even more). Firms therefore have a relatively clear view of the process as well as of the probability of winning their case. All the more so that (roughly) one fourth of dismissals end in court; most employers have experienced multiple trials.

\section{Robustness Checks}

The effects of our judicial outcomes on job flows are large. In order to assess their plausibility we provide several robustness assessments. As a first check, Table 8 reports IV estimates with other instruments than the lawyers' availability rate. All estimates are extremely similar to those with the lawyer instrument.

The second check exploits a natural experiment ran at the local level in the jurisdiction of Grenoble. Grenoble is a city located at the foot of the French Alps in southeastern France. The jurisdiction of the labor court of Grenoble is the $15^{\text {th }}$ largest jurisdiction in terms of its 1999 labor force $(254,567)$. In 1996, in order to facilitate dispute resolution the French Parliament passed a law empowering the judges to mandate a mediator. This law went unheeded since labor courts were already supposed to invite the parties to stop the case before trial thanks to the mandatory stage of conciliation. In 1995, the judge Blohorn-Brenneur was appointed at the Circuit court of appeals of Grenoble and decided to exploit the possibilities offered by this law in order to boost the conciliation process. Starting in 1998, this was done by a) sending out an information letter and a questionnaire to the parties in order to increase parties' awareness of mediation, b) offering mediation and conflict management training to the judges of Grenoble, and c) organizing specific hearings where mediation services were proposed to the parties. ${ }^{30}$ We will see that this experiment led to a strong increase in the conciliation rate from 1998 onwards at the Grenoble jurisdiction. In order to assess its impact on job flows, we run a simple difference in difference regression of the form:

$$
\text { Flows }_{p, t}=\alpha_{1} B C_{p, t}+\alpha_{2} B C_{p, t-1}+\beta \times \text { Grenoble } \text { Post1998 }+\delta_{p}+\gamma_{t}+\varepsilon_{p, t}
$$

\footnotetext{
30 See Blohorn-Brenneur (2010) in «Refondation du droit social, concilier protection des travailleurs et efficacité économique », Jean Barthélémy et Gilbert Cette, Rapport du Conseil Economique et Social. The summary in English of the whole report is to be found page 191-197. The Judge Blohorn-Brenneur founded with others the European Association of Judges for Mediation in 2003.
} 
where Grenoble is an indicator equal to one for the jurisdiction of Grenoble interacted with an indicator equal to one during the treatment period (1998-2003). We present in Table 9 the estimates of equation (4) using different control groups. First, we use all other French jurisdictions. Results are presented in the first panel of Table 9. Then, because some local specific shocks might put at risk the identifying assumption of this first difference-in-difference method, we consider the following control groups 1) the jurisdictions of similar sizes (i.e. with a 1999 labor force between 150,000 and 400,000) and 2) the jurisdictions surrounding the Grenoble jurisdiction (the other jurisdictions within Isère, the 'département' where Grenoble is located and the jurisdictions belonging to 'départements' contiguous to Isere). Results are presented in the second and third panel of Table 9, respectively. The last column of this table presents the estimated impact of the experiment on the conciliation rate (i.e. the estimates of $\beta$ associated with equation (4) where the conciliation rate is the endogenous variable). First, focusing on this last column, and as claimed above, the Grenoble experiment increased substantially the conciliation rate by around 8 percentage points, i.e. about one standard deviation of the conciliation rate measured across years and jurisdictions. The difference is similar when Grenoble is compared to contiguous jurisdictions and jurisdictions of similar size. Turning to the impact of the experiment on labor flows, as already obtained in our instrumental approach, a higher conciliation rate dampens job destructions. Although obtained on slightly different time periods and with different identification strategies, (interpretable as a local average treatment effect, as suggested by Imbens and Angrist, 1994), the two measures of the causal impact of the conciliation rate on job destructions have similar magnitudes. A one standard deviation increase in the conciliation rate leads to an increase in the job destruction rate of 2-4 percentage points (e.g. one standard deviation) using the difference-indifference estimates and of 6 percentage points using the instrumental regressions (i.e. 1.5 standard deviation).

As an additional test, we propose a falsification procedure based on the different provisions protecting from unfair dismissals different types of workers. By law, firing constraints are reduced for workers who have less than two years of seniority. In their case, the severance payment due for the absence of "real and serious cause" is not subject to the minimum amount of 6 months of wage but is limited to a compensatory award, potentially equal to zero if the worker has found a new job. Therefore, destruction flows for such workers should not be affected by judicial outcomes. Because we need a source with seniority when leaving a firm, we use the French labor force survey, in order to compute the ratio of workers that have been dismissed within the year with seniority less than two years over the number of employees in the private sector. Unfortunately, the labor force survey does not allow locating the place of work within each jurisdiction. The indicators are thus built at a slightly larger geographical level, the 'département” level with one 'département' comprising on average three jurisdictions. 
Because we work at a more aggregate level and within a shorter period, ${ }^{31}$ our instruments lose some of their explanatory power. However, the lawyer density measured at the 'département' level keeps its strong explanatory power when used to explain the worker lawyer rate as well as the conciliation rate (see Table 10a). Hence, we present IV results for these two outcomes. The results are presented in Table 10b. First, we test whether we find results that look similar to those obtained in Table 8, based on more aggregate data. Then, we examine the impact on those workers with less than two years seniority. The estimates are presented in the last column of Table 10b. Comparing the first three columns with the estimates of Table 8, we see that the magnitude of the coefficients is very similar, albeit only significant for the worker lawyer rate. Now, as expected, it is zero for the inflows of short tenured workers into unemployment for both variables.

As an additional check for assessing the impact of the conciliation rate on labor flows, we consider the time it takes to go from the filing of the case to a conciliation hearing. Our model does not say much on the duration of trials. However, this filing-to-conciliation time is likely to be related to the intensity of the bargaining between the parties. Indeed, a regression of the conciliation rate on the filing-toconciliation time with jurisdiction fixed effects, time, and business cycle indicators shows that the two variables are positively related, albeit mildly. ${ }^{32}$ Hence, successful conciliation takes time. Indeed, even though labor laws stipulate that the first conciliation hearing should take place within the first month following filing, variability across départements and time is large (see Table A.4). Many reasons may explain this variability, more particularly court congestion and, as indicated above, the bargaining process taking place in the shadow of the law. Our first-stage regression estimates underline these two contrasting effects: an increase in the number of clerks in the court decreases the time to conciliation when a stronger presence of lawyers in the jurisdiction has the opposite effect (see table A.5). Turning to the causal impact of the filing-to-conciliation time on labor flows, the results are essentially similar to those obtained for the conciliation rate, keeping in mind that a longer time to reach an agreement is associated with a higher conciliation rate, and lawyers increasing both conciliation and the time from filing to conciliation (see Table A.6).

\section{Conclusion}

This article examines the impact of judicial activity on labor markets for France using an original data set of individual labor disputes brought to court over the years 1996 to 2003. First, we present a simple theoretical model allowing us to relate judicial case outcomes with changes in the firing costs. Its use for our empirical analysis is twofold. First, we use it to generate instruments, based on the French

\footnotetext{
${ }^{31}$ Changes in the LFS in 2003 do not allow us to expand our estimation period.

${ }^{32}$ Results are available from the authors.
} 
institutional setting and the local legal environment. For instance, because lawyers tend to open their practice close to the university they were enrolled at, changes in their numbers are unrelated to the number of cases in each labor court except through the litigation costs. Second, the model shows that changes in litigation costs have ambiguous effects. To see this, consider the fraction of cases that go to trials. Firms faced with a negative shock on litigation costs will fire their personnel for personal motive and risk litigation more often rather than fire them for economic motives, avoid lawsuits but pay a large (and regulated) firing cost. In this situation, a larger trial rate is associated with lower firing costs. However, workers faced with a negative shock on litigation costs are more likely to sue the firm. By contrast, a larger trial rate is now associated with higher firing costs. The empirical analysis will help us resolve this ambiguity.

Using the lawyer instrument, as well as other instruments to assess robustness of our results, we show that case outcomes have a causal effect on labor flows. More trials and a higher victory rate at trial for workers cause increased job destruction. More settlements/conciliations before trial, higher filing rates, larger fractions of workers represented at trial dampen job destruction. We conduct various checks using alternative strategies that confirm our results.

The web of legislations and the variety of local situations affect the enforcement of legislation and court outcomes. In turn, the process of job creation and job destruction is affected. Micro-analyses using specificities of the situation at hand appear to be useful, at least in the French context, to identify the mechanisms underlying such process. 


\section{References}

Algan, Y. and P. Cahuc, (2009), “Civic Virtue and Labor Market Institutions,” American Economic Journal: Macroeconomics, 1 (1): 111-45.

Andolfatto D., (1992), L'univers des élections professionnelles. Travail et société au crible des urnes. Paris, Editions de l'Atelier.

Autor, D. H., (2003), “Outsourcing at Will: The Contribution of Unjust Dismissal Doctrine to the Growth of Employment Outsourcing,” Journal of Labor Economics, 21 (1), January, 1 - 42.

Autor D. H., J. J. Donohue and S. J. Schwab, (2006), “The Costs of Wrongful-Discharge Laws,” The Review of Economics and Statistics, 88 (2), 211-231.

Bartik, T. J., (1991), Who Benefits from State and Local Economic Development Policies? Kalamazoo, Mich.: W. E. Upjohn Institute for Employment Research.

Bauer, T., S. Bender, and H. Bonin, (2007), “Dismissal Protection and Worker Flows in Small Establishments,” Economica, 74 (296), 804-821.

Bebchuk L. A., (1984), "Litigation and Settlement under Imperfect Information," The RAND Journal of Economics, 15 (3), 404-415.

Beenstock M., and Y. Haitovsky, (2004), "Does the appointment of judges increase the output of the judiciary ?”, International Review of Law and Economics, 24, 351-369.

Bentolila S. and G. Bertola, (1990), ”Firing Costs and Labor Demand: How Bad is Eurosclerosis?”, The Review of Economic Studies, 57 (3), 381-402.

Bertola, G., (1992), “Labor Turnover Costs and Average Labor Demand,” Journal of Labor Economics, 10, 389411.

Bertola, G., (2004), ”A Pure Theory of Job Security and Labour Income Risk,” Review of Economic Studies, 71 (1), 43-61.

Bertrand, M., and F. Kramarz, (2002), "Does Entry Regulation Hinder Job Creation? Evidence From The French Retail Industry," Quarterly Journal of Economics, 107 (4), 1369-1413.

Besancenot, D. and R. Vranceanu, (2009), “Multiple equilibria in a firing game with impartial justice,” Labour Economics, 16 (3), 262-271.

Bhattacharya, U. and H. Daouk, (2002), “The World Price of Insider Trading,” Journal of Finance, 57, 75-108.

Blanchard O., and L. F. Katz, (1992), “Regional Evolutions,” Brookings Papers on Economic Activity, 1, 1-75.

Blanchard, O. and T. Philippon, (2004), “The Quality of Labor Relations and Unemployment,” NBER Working Paper 10590.

Blohorn-Brenneur, B., (2010), “La médiation prud’homale,” in « Refondation du droit social, concilier protection des travailleurs et efficacité économique », Jean Barthélémy et Gilbert Cette, Rapport du Conseil Economique et Social, 143-151.

Boeri, T., and J. F. Jimeno, (2005), "The effects of employment protection: Learning from variable enforcement,” European Economic Review, 49 (8), 2057-2077.

Bonafé-Schmidt J. P., (1987), “Les prud'hommes: du conseil de discipline à la juridiction de droit commun du travail,” Le Mouvement social, 141, Les Prud’hommes XIXe-XXe Siècle, 121-148.

Burgess, S., Popper, C. and D. Wilson, (2001) "Explaining the growth in the number of applications to employment tribunals 1972-1997.” Department of Trade and Industry. 
Card, D., and B. P. McCall, (2009), "When to Start a Fight and When to Fight Back: Liability Disputes in the Workers' Compensation System,” Journal of Labor Economics, 27 (2), 149-178.

Chemin, M and E. Wasmer, (2009). 'The employment effects of 35-hour workweek regulation in France: using Alsace-Moselle local laws to build a diff-in-diff', Journal of Labor Economics, 27 (4), 487-524.

Davis S., and J. C. Haltiwanger, (1992), "Gross Job Creation, Gross Job Destruction, and Employment Reallocation,” Quarterly Journal of Economics, 819-864.

Dertouzos, J. N., (1988), “The End of Employment-at-Will: Legal and Economic Costs,” Report P-7441. Santa Monica, Calif.: Rand Corp.

Devereux P. and R. Hart, (2011), “A good time to stay out? Strikes and the business cycle,” British Journal of Industrial Relations (forthcoming).

Flanagan, M., (1989), “Compliance and Enforcement Decision under the National Labor Relations Act,” Journal of Labor Economics, 7 (3), 257-280.

Freeman R. B., (2005), "Labor Market Institutions Without Blinders: The Debate over Flexibility and Labor Market Performance,” NBER Working Paper 11286.

Harrison A. and M. Stewart, (1994), “Is Strike Behavior Cyclical ?”, Journal of Labor Economics, 12 (4), $524-$ 553.

Ichino, A., M. Polo and E. Rettore, (2003), “Are Judges Biased by Labor Market Conditions ?”, European Economic Review, 47 (5), 913-944.

Lazear E. P., (1990), “Job Security Provision and Employment”. Quarterly Journal of Economics, 105 (3), 699 726.

Marinescu, I., (2008), “Are Judges Sensitive to Economic Conditions? Evidence from UK Employment Tribunals,” working paper.

Marinescu, I., (2009), “Job Security Legislation and Job Duration ? Evidence from the UK,” Journal of Labor Economics, 27 (3), 475-486.

Martins, P. S., (2009), “Dismissals for Cause: The Difference That Just Eight Paragraphs Can Make,” Journal of Labor Economics, 27 (2), 257-280.

Munoz-Perez B., and E. Serverin, (2006), “Le sort des demandes prud'homales en 2004,” Bulletin d'information statistique, Ministère de la Justice, 87.

OECD, (2004), Employment Outlook, OECD Publication, Paris.

Oyer, P., and S. Schaefer, (2000), “Layoffs and Litigation,” The RAND Journal of Economics, 31 (2), 345-358.

Priest, G. and B. Klein, (1984), “The selection of disputes for litigation,” Journal of Legal Studies, 13, 1-55.

Siegelman, P., and J. J, III, Donohue, (1995), “The Selection of Employment Discrimination Disputes for Litigation: Using Business Cycle Effects to Test the Priest-Klein Hypothesis,” Journal of Legal Studies, 24 (2), 427-62.

Spier, K., (2007), "Litigation” in The Handbook of Law and Economics (A. M. Polinsky and S. Shavell, eds., North Holland).

Stähler, N., (2008), “Firing costs, severance payments, judicial mistakes and unemployment," Labour Economics, 15 (6), 1162-1178. 
Stevenson, B., (2007), “The Impact of Divorce Laws on Investment in Marriage Specific Capital,” Journal of Labor Economics, 25 (1), 75-94.

Venn, D., (2009), "Legislation, Collective Bargaining and Enforcement: Updating the OECD Employment Protection Indicators”, OECD Social, Employment and Migration Working Papers, 89. 


\section{Model Appendix:}

The employer dismisses the worker at the minimum cost, instead of paying the maximum severance payments, if:

$$
p_{f}\left\{p_{c}\left(c_{c}+l_{c}\right)+\left(1-p_{c}\right)\left[p_{w}\left(c_{m}+F\right)+\left(1-p_{w}\right) c_{m}+l_{t}\right]\right\}+\left(1-p_{f}\right) c_{m}<c_{M}
$$

As for the worker, she chooses to challenge her dismissal $\left(p_{f}=1\right)$ if her expected gain at trial or at the conciliation stage is larger than the minimum severance payment:

$$
p_{w}\left(c_{m}+F\right)+\left(1-p_{w}\right) c_{m}-k_{t}>c_{m} \text { or } c_{c}-k_{c}>c_{m}
$$

Thus the worker chooses to go to court if the gain at trial is large enough $\left(p_{w}\left(c_{m}+F\right)+\left(1-p_{w}\right) c_{m}-k_{t}>c_{m}\right.$, that is $\left.p_{w}>\overline{p_{w}}=\frac{k_{t}}{F}\right)$. The worker would prefer the agreement $\left(p_{c}=1\right)$ than the trial when $p_{w}\left(c_{m}+F\right)+\left(1-p_{w}\right) c_{m}-k_{t}<c_{c}-k_{c}$, i.e.

$$
p_{w}<\overline{\overline{p_{w}}}=\frac{c_{c}-c_{m}+k_{t}-k_{c}}{F}
$$

Yet the firm can refuse the agreement.

On the firm side, the firm dismisses the worker offering the minimum cost if:

$$
p_{w}\left(c_{m}+F\right)+\left(1-p_{w}\right) c_{m}+l_{t}<c_{M}
$$

that is:

$$
p_{w}<p_{w}^{* *}=\frac{c_{M}-c_{m}-l_{t}}{F}
$$

We assume that the compensatory award $F$ is large enough so that when the firm is certain to lose at trial, it is less costly to pay the maximum severance payment. That is: $c_{M}<c_{m}+F+l_{t}$ and thus $p_{w}^{* *}<1$.

In addition, the firm accepts the conciliation only if it is less costly than going to trial, that is:

$$
p_{w}\left(c_{m}+F\right)+\left(1-p_{w}\right) c_{m}+l_{t}>c_{c}+l_{c}
$$

which means:

$$
p_{w}>p_{w}^{*}=\frac{c_{c}-c_{m}-l_{t}+l_{c}}{F}
$$

In order a conciliation to exist, suing must be a credible threat to the employer. Therefore, we impose that $p_{w}^{*}<\overline{p_{w}}$ that is $c_{c}-c_{m}+l_{c}<k_{t}+l_{t}$. In addition, there must a probability range where the worker is better off to conciliate than going to trial. We must have $\overline{p_{w}}<\overline{\overline{p_{w}}}$ that is $c_{m}<c_{c}-k_{c}$.

Finally, for the trial stage to exist, the firm must be better off in some probability range to go to trial rather than giving the compensatory award $c_{M}$ that protects against any suing: $\overline{\overline{p_{w}}}<p_{w}^{* *}$.

To summarize, we have five assumptions:

\section{Assumptions:}

Condition (1): $k_{t}>c_{c}-c_{m}+l_{c}-l_{t}$ : the cost of trial is sufficiently large $\left(p^{*}{ }_{w}<\overline{p_{w}}\right)$ 
Condition (2): $c_{c}-k_{c}>c_{m}$ : the gain for the worker at the conciliation stage is larger than the severance payment she receives in case of firing for a personal motive $\left(\overline{p_{w}}<\overline{\overline{p_{w}}}\right)$.

Condition (3): $c_{c}+l_{c}<c_{M}$ : the cost for the firm at the conciliation stage is smaller than the severance payment received by the worker in case of firing for an economic motive.

Conditions (1), (2) and (3) taken together allow for the possibility of a conciliation stage.

Condition (4): The compensatory award $F$ is large enough so that when the firm is certain to lose at trial, it is less costly to pay the maximum severance payment. That is: $c_{M}<c_{m}+F+l_{t}$. It implies $p_{w}^{* *}<1$ and excludes an equilibrium in which the law has no deterrent effect, every worker being fired for a personal motive.

Condition (5): $c_{c}-k_{c}+k_{t}+l_{t}<c_{M}$ : there is a probability range for a trial to exist. The firm is better off at trial than paying $c_{M}$.

\section{Result:}

Under these assumptions we end up with four equilibria:

- $p_{f}=0$ and $p_{c}=0$ if $p_{w}<\overline{p_{w}}$

- $p_{f}=1$ and $p_{c}=1$ if $\bar{p}_{w}<p_{w}<\bar{p}_{w}$ (with $p_{w}^{*}<\overline{p_{w}}$ )

- $p_{f}=1$ and $p_{c}=0$ if $\overline{\overline{p_{w}}}<p_{w}<p_{w}^{* *}$

- the firm pays $c_{M}$ if $p_{w}>p_{w}^{* *}$ 
Figure 4: Number of Filed Cases

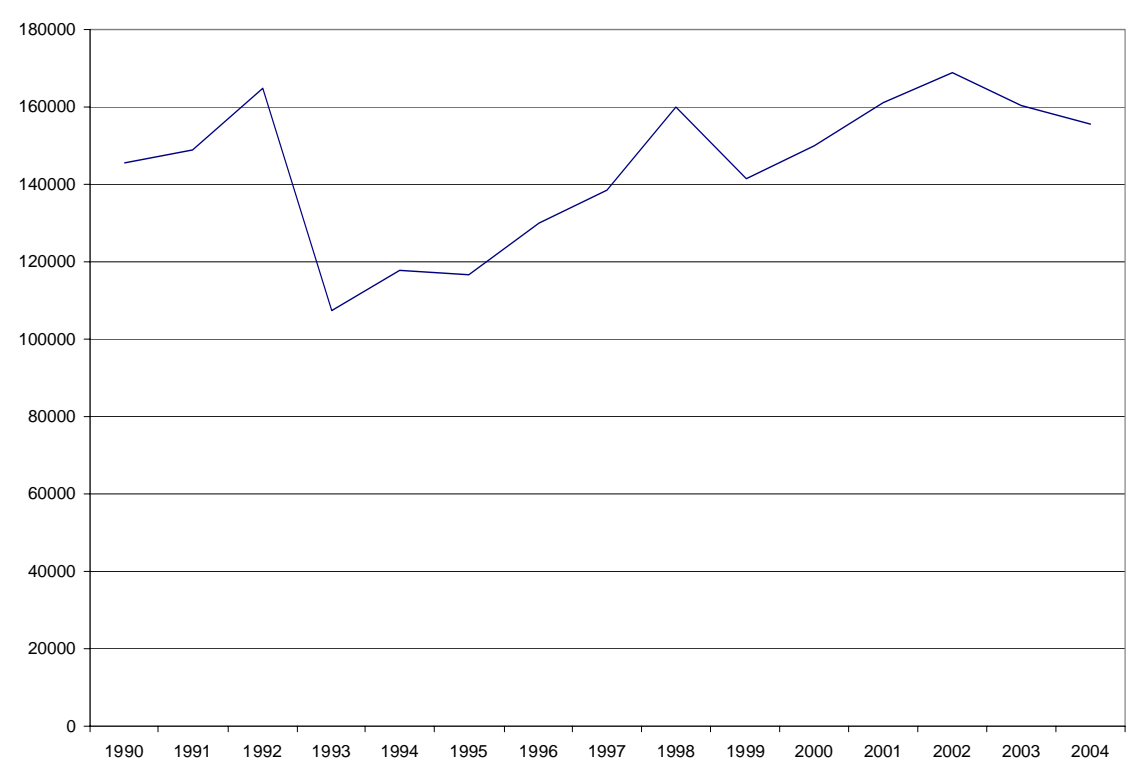

Figure 5: Map of the Universities Training Lawyers

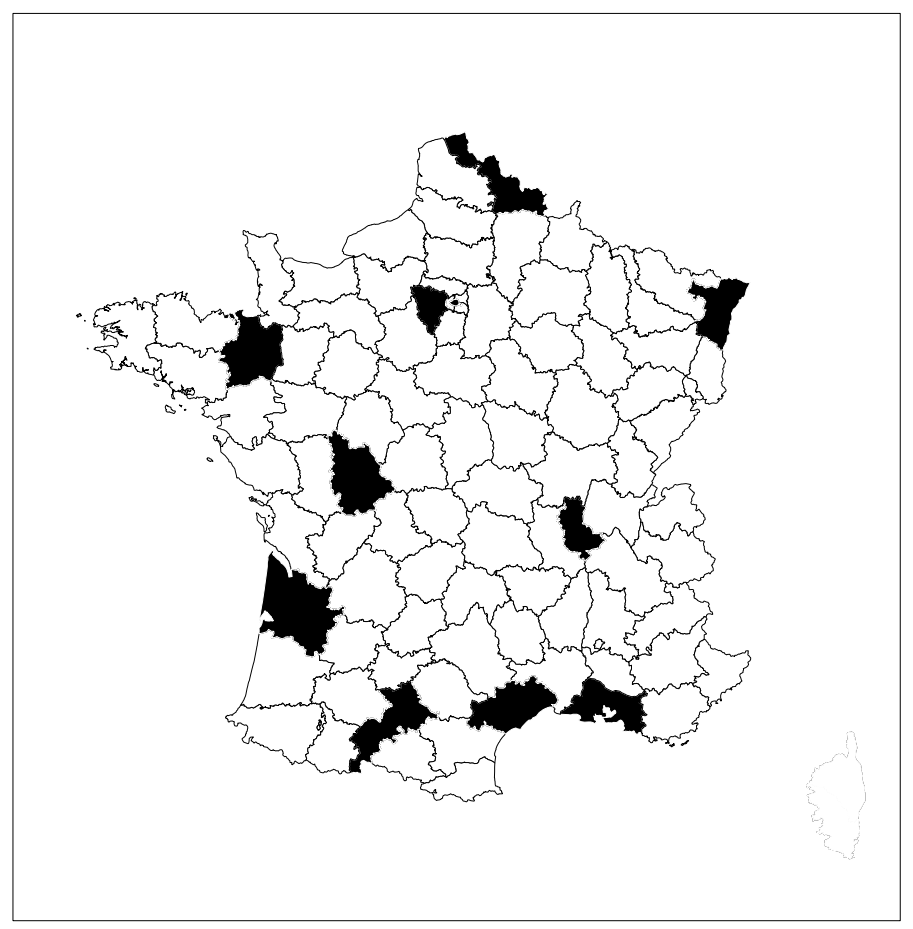


Figure 6: Map of the Changes in the Lawyer Density between 1996 and 2003

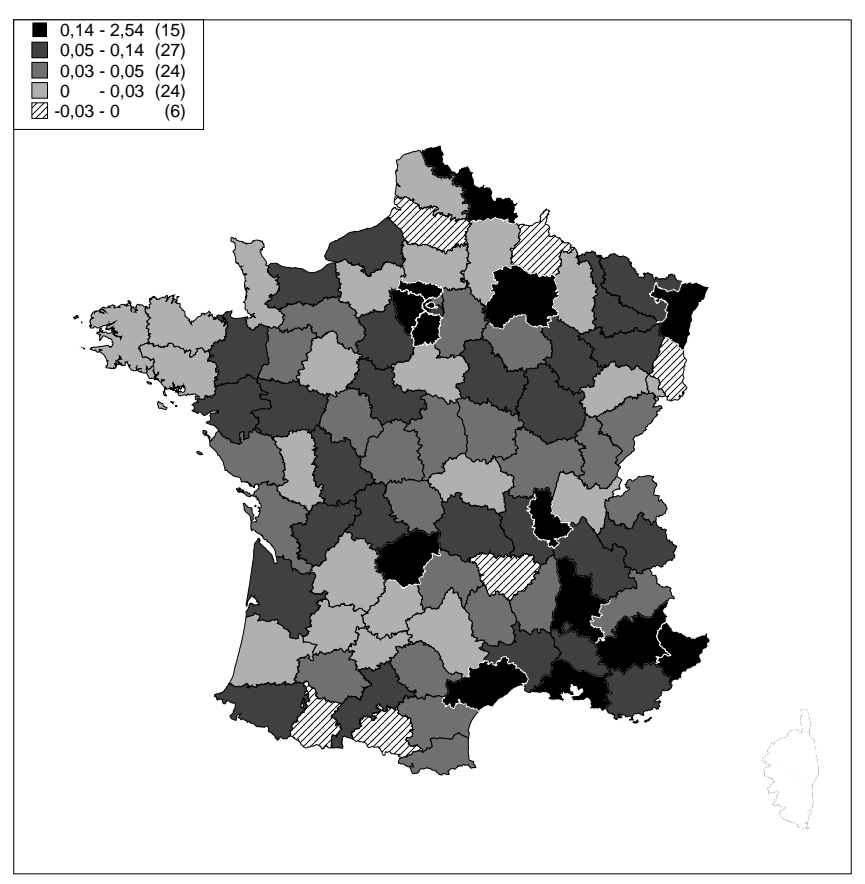


Table 1: Judicial Indicators: Definition of Variables

\begin{tabular}{c|l}
\hline \hline Names & \multicolumn{1}{c}{ Definition } \\
\hline Filing rate & Number of cases filed over number of dismissals \\
Worker Lawyer rate & $\begin{array}{l}\text { Number of cases where the worker is represented by a lawyer over the } \\
\text { total number of cases } \\
\text { Number of cas es leading to a conciliation or an agreement between the } \\
\text { parties over the total number of cases } \\
\text { Number of cases reaching the trial stage over the total number of cases } \\
\text { Trial rate }\end{array}$ \\
Winning rate & $\begin{array}{l}\text { Number of cases won by the worker at trial over the total number of } \\
\text { cases }\end{array}$ \\
\hline \hline
\end{tabular}

Notes: These variables are comp uted at the jurisdiction level (jurisdiction*year)

Table 2: Summary Statistics: Judicial Indicators and Job Flows

\begin{tabular}{lcccc}
\hline \hline $\begin{array}{l}\text { Judicial Indicators: } \\
\quad \text { Mean }\end{array}$ & Std. & Min & Max \\
$\quad$ Filing rate & 0,22 & 0,11 & 0,03 & 0,98 \\
$\quad$ Worker Lawyer rate & 0,48 & 0,15 & 0,00 & 0,95 \\
$\quad$ Conciliation rate & 0,20 & 0,09 & 0,00 & 0,77 \\
$\quad$ Trial rate & 0,61 & 0,10 & 0,19 & 0,95 \\
$\quad$ Worker winning rate & 0,45 & 0,09 & 0.09 & 0,93 \\
Job Flows: & & & & \\
$\quad$ Job Destructions & 0,16 & 0,04 & 0,07 & 0,52 \\
$\quad$ Job Creations & 0,16 & 0,06 & 0,05 & 0,71 \\
$\quad$ Net Job Creations & 0,00 & 0,07 & $-0,63$ & 0,43 \\
\hline \hline
\end{tabular}

Notes: Means of the jurisdition*year indicators, over the 264 jurisdictions and the years 1996-2003. Because cases can also be dropped, the sum of the trial rate and of the conciliation rate is smaller than 1.

Table 3: Number of Judges by Section and Change over the Electoral Terms

\begin{tabular}{lc|c|c}
\hline \hline & & \multicolumn{2}{|c}{ Change in \% between term t and term t-1 } \\
& Number of judges in 1992 & $1997 / 1992$ & $2002 / 1997$ \\
\hline Manufacturing & 1,881 & 0 & -9 \\
Service & 1,266 & 0 & 11 \\
Trade & 1,923 & 0 & 1 \\
Management & 1,406 & 0 & 4 \\
\hline Total & 6,522 & 0 & 1 \\
\hline
\end{tabular}


Table 4: Changes in the Numbers of Judges across the Sections of the 264 Jurisdictions

\begin{tabular}{c|c|c|c|c}
\hline \hline \multicolumn{5}{c}{ 2002 Election } \\
\hline & Manufacturing & Service & Trade & All sections \\
\hline lost 3 judges or more & 7 & 0 & 0 & 8 \\
lost 2 judges & 8 & 0 & 0 & 11 \\
lost 1 judges & 27 & 1 & 25 & 22 \\
no change & 56 & 79 & 58 & 44 \\
gained 1 judges & 1 & 9 & 9 & 6 \\
gained 2 judges & 1 & 5 & 3 & 3 \\
gained 3 judges or & 0 & 6 & 4 & 6 \\
more & & & & \\
\hline \hline
\end{tabular}

Note: read as \% of jurisdictions that lost (or gained or no change) $\mathrm{x}$ judges in the election year $t$

Table 5a: First Stage Regressions: Effect of Legal Inputs on Judicial Indicators

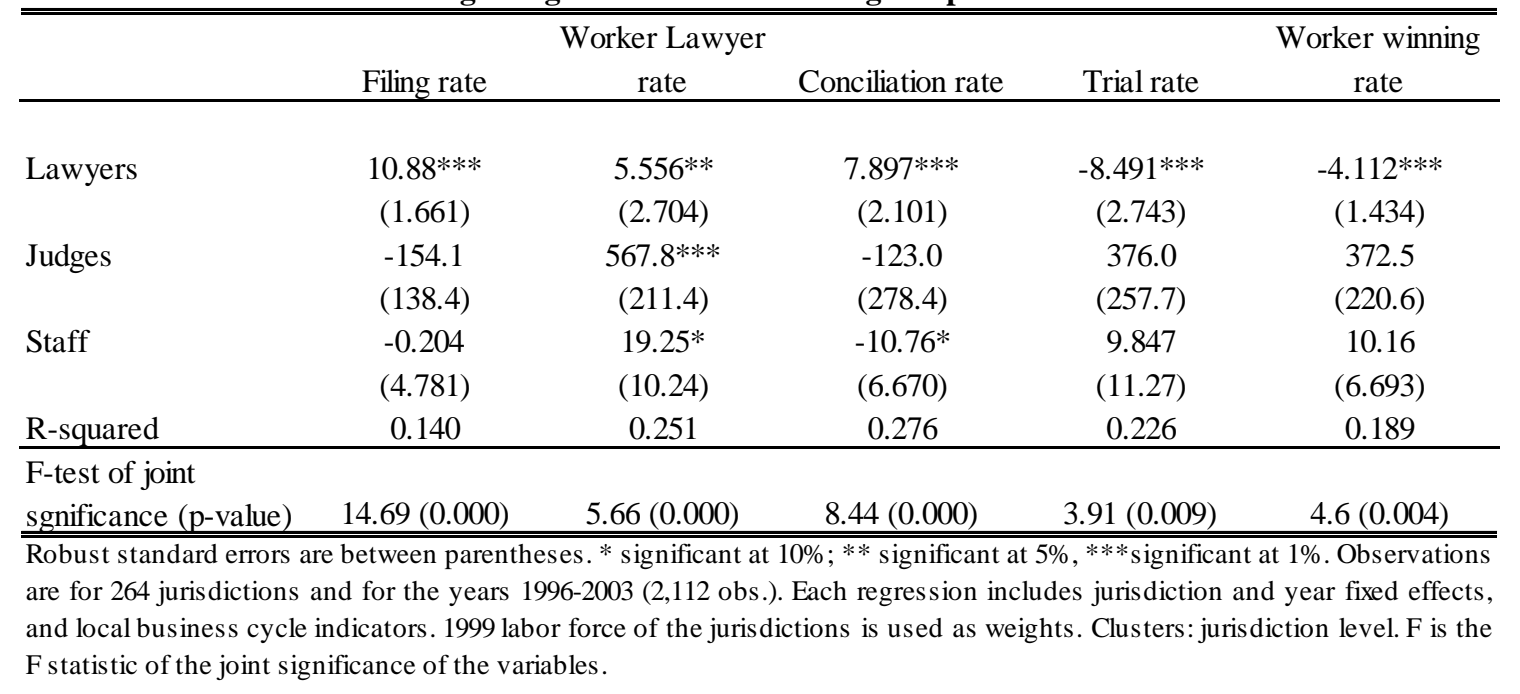


Table 5b: First Stage Regressions: Effect of Legal Inputs on Judicial Indicators

\begin{tabular}{|c|c|c|c|c|c|}
\hline & \multicolumn{3}{|c|}{ Worker Lawyer } & \multicolumn{2}{|r|}{ Worker winning } \\
\hline & Filing rate & rate & Conciliation rate & Trial rate & rate \\
\hline Lawyers & $\begin{array}{c}10.39 * * * \\
(1.629)\end{array}$ & $\begin{array}{l}5.524^{*} \\
(2.833)\end{array}$ & $\begin{array}{c}7.331^{* * *} \\
(2.059)\end{array}$ & $\begin{array}{c}-7.539 * * * \\
(2.647)\end{array}$ & $\begin{array}{c}-3.864^{* * *} \\
(1.347)\end{array}$ \\
\hline R-squared & 0.140 & 0.243 & 0.273 & 0.221 & 0.186 \\
\hline $\begin{array}{l}\text { F-test of joint } \\
\text { sgnificance ( } p \text {-value) }\end{array}$ & $40.68(0.000)$ & $3.8(0.052)$ & $12.67(0.000)$ & $8.11(0.004)$ & $8.21(0.000)$ \\
\hline
\end{tabular}

Table 5c: First Stage Regressions: Effect of Legal Inputs on Judicial Indicators

\begin{tabular}{|c|c|c|}
\hline & Worker Lawyer rate & Conciliation rate \\
\hline Lawyers & & $\begin{array}{c}7.772 * * * \\
(1.934)\end{array}$ \\
\hline Judges & $\begin{array}{c}646.8^{* * *} \\
(187.8)\end{array}$ & \\
\hline Staff & & $\begin{array}{l}-10.80 * \\
(6.675)\end{array}$ \\
\hline R-squared & 0.259 & 0.276 \\
\hline $\begin{array}{l}\text { F-test of joint } \\
\text { sgnificance (p-value) }\end{array}$ & $11.93(0.000)$ & $12.39(0.000)$ \\
\hline
\end{tabular}


Table 6: Judicial Indicators on Job Flows: Reduced-form Regressions

\begin{tabular}{lccc}
\hline \hline & Job Destructions & Job Creations & Net Job Creations \\
\hline Lawyers & $-5.734^{* * *}$ & -0.832 & $4.902^{* * *}$ \\
& $(1.181)$ & $(1.065)$ & $(1.650)$ \\
Judges & $-511.4^{* * *}$ & $-158.7^{*}$ & $352.7^{* *}$ \\
\multirow{2}{*}{ Staff } & $(139.8)$ & $(83.26)$ & $(149.1)$ \\
& 6.863 & -2.125 & $-8.989^{* *}$ \\
& $(4.263)$ & $(2.037)$ & $(3.647)$ \\
R-squared & & & 0.565 \\
\hline \hline
\end{tabular}

Robust standard errors are between parentheses. * significant at 10\%; ${ }^{* *}$ significant at 5\%, ${ }^{* * *}$ significant at $1 \%$. Observations are for 264 jurisdictions and for the years 1996-2003 (2,112 obs.). Each regression includes jurisdiction and year fixed effects, and local business cycle indicators. 1999 labor force of the jurisdictions is used as weights. Clusters: jurisdiction level.

Table 7: Judicial Indicators on Job Flows: OLS Estimates

\begin{tabular}{lccc}
\hline \hline & Job Destructions & Job Creations & Net Job Creations \\
\hline Filing rate & 0.0169 & -0.00703 & -0.0239 \\
& $(0.0188)$ & $(0.0126)$ & $(0.0212)$ \\
R-squared & 0.43 & 0.48 & 0.59 \\
\hline Worker Lawyer rate & $-0.0469^{* *}$ & -0.00588 & $0.0410^{* *}$ \\
& $(0.0182)$ & $(0.0103)$ & $(0.0199)$ \\
R-squared & 0.41 & 0.47 & 0.56 \\
\hline Conciliation rate & $-0.0439^{* *}$ & -0.00504 & $0.0389^{*}$ \\
& $(0.0222)$ & $(0.0134)$ & $(0.0221)$ \\
R-squared & 0.40 & 0.47 & 0.56 \\
\hline Trial rate & $0.0363^{* *}$ & 0.00431 & -0.0320 \\
& $(0.0180)$ & $(0.0114)$ & $(0.0209)$ \\
R-squared & 0.40 & 0.47 & 0.56 \\
\hline Worker Winning rate & $0.0382^{* *}$ & 0.00704 & -0.0312 \\
R-squared & $(0.0185)$ & $(0.0117)$ & $(0.0211)$ \\
\hline \hline
\end{tabular}

Robust standard errors are between parentheses. * significant at 10\%; ** significant at 5\%, ***significant at 1\%. Observations are for 264 jurisdictions and for the years 1996-2003 (2,112 obs.). Each regression includes jurisdiction and year fixed effects, and local business cycle indicators. 1999 labor force of the jurisdictions is used as weights. Clusters: jurisdiction level. 
Table 8: Judicial Indicators on Job Flows: 2SLS Estimates

\begin{tabular}{|c|c|c|c|}
\hline & Job Destructions & Job Creations & Net Job Creations \\
\hline Filing rate & $\begin{array}{c}-0.674^{* * *} \\
(0.179)\end{array}$ & $\begin{array}{c}-0.272 * * \\
(0.131)\end{array}$ & $\begin{array}{l}0.402^{*} \\
(0.214)\end{array}$ \\
\hline \multicolumn{4}{|l|}{ Instruments: Lawyers } \\
\hline R-squared & 0.215 & 0.314 & 0.459 \\
\hline Worker Lawyer rate & $\begin{array}{c}-1.132^{*} \\
(0.603)\end{array}$ & $\begin{array}{l}-0.191 \\
(0.159)\end{array}$ & $\begin{array}{c}0.941 \\
(0.629)\end{array}$ \\
\hline \multicolumn{4}{|l|}{ Instruments: Lawyers } \\
\hline R-squared & 0.201 & 0.172 & 0.286 \\
\hline Worker Lawyer rate & $\begin{array}{c}-1.065^{* * *} \\
(0.373)\end{array}$ & $\begin{array}{c}-0.205^{*} \\
(0.116)\end{array}$ & $\begin{array}{c}0.859^{* *} \\
(0.371)\end{array}$ \\
\hline \multicolumn{4}{|l|}{ Instruments: Judges } \\
\hline R-squared & 0.375 & 0.355 & 0.56 \\
\hline Conciliation rate & $\begin{array}{c}-0.853^{* * *} \\
(0.297)\end{array}$ & $\begin{array}{l}-0.144 \\
(0.142)\end{array}$ & $\begin{array}{c}0.709^{* *} \\
(0.314)\end{array}$ \\
\hline \multicolumn{4}{|l|}{ Instruments: Lawyers } \\
\hline R-squared & 0,443 & 0.411 & 0.246 \\
\hline Conciliation rate & $\begin{array}{c}-0.772 * * * \\
(0.216)\end{array}$ & $\begin{array}{l}-0.0699 \\
(0.129)\end{array}$ & $\begin{array}{c}0.702^{* * *} \\
(0.268)\end{array}$ \\
\hline \multicolumn{4}{|l|}{ Instruments: Lawyers and staff } \\
\hline R-squared & 0.278 & 0.446 & 0.253 \\
\hline Trial rate & $\begin{array}{c}0.829^{* *} \\
(0.344)\end{array}$ & $\begin{array}{c}0.140 \\
(0.168)\end{array}$ & $\begin{array}{c}-0.689 * * \\
(0.278)\end{array}$ \\
\hline \multicolumn{4}{|l|}{ Instruments: Lawyers } \\
\hline R-squared & 0.735 & 0.401 & 0.132 \\
\hline Worker Winning rate & $\begin{array}{c}1.617 * * * \\
(0.608)\end{array}$ & $\begin{array}{c}0.273 \\
(0.305)\end{array}$ & $\begin{array}{c}-1.345^{* *} \\
(0.541)\end{array}$ \\
\hline \multicolumn{4}{|l|}{ Instruments: Lawyers } \\
\hline R-squared & 0,31 & 0.281 & 0.191 \\
\hline
\end{tabular}

Robust standard errors are between parentheses. * significant at 10\%; ** significant at 5\%, ***significant at $1 \%$. Observations are for 264 jurisdictions and for the years 1996-2003 (2,112 obs.). Each regression includes jurisdiction and year fixed effects, and local business cycle indicators. 1999 labor force of the jurisdictions is used as weights. Clusters: jurisdiction level. 
Table 9: Impact of the Conciliation Rate: Difference-in-Difference Estimates of the Brenner Experiment

\begin{tabular}{|c|c|c|c|c|}
\hline & Job Destructions & Job Creations & Net Job Creations & Conciliation rate \\
\hline \multicolumn{5}{|l|}{ Treatment Group: Jurisdiction of Grenoble } \\
\hline \multicolumn{5}{|l|}{ Control Group: Rest of France } \\
\hline \multicolumn{5}{|l|}{ Observations = 3393 (263 jurisdictions $)$} \\
\hline Grenoble*Post1998 & $-0.0371 * * *$ & $-0.0297 * * *$ & $0.00732 * * *$ & $0.0833^{* * *}$ \\
\hline & $(0.00185)$ & $(0.00171)$ & $(0.00178)$ & $(0.00389)$ \\
\hline R-squared & 0.332 & 0.376 & 0.463 & 0.109 \\
\hline \multicolumn{5}{|l|}{ Control Group: Jurisdictions of Similar Size } \\
\hline \multicolumn{5}{|l|}{ Observations = 494 (38 jurisdictions) } \\
\hline Grenoble*Post1998 & $-0.0414 * * *$ & $-0.0352 * * *$ & 0.00624 & $0.0642 * * *$ \\
\hline & $(0.00335)$ & $(0.00376)$ & $(0.00388)$ & $(0.00630)$ \\
\hline R-squared & 0.384 & 0.499 & 0.560 & 0.297 \\
\hline \multirow{2}{*}{\multicolumn{5}{|c|}{$\begin{array}{l}\text { Control Group: Jurisdictions within Contiguous Départements } \\
\text { Observations = } 416 \text { ( } 32 \text { jurisdictions) }\end{array}$}} \\
\hline & & & & \\
\hline Grenoble*Post1998 & $-0.0206 * * *$ & $-0.0167 * * *$ & 0.00384 & $0.0711 * * *$ \\
\hline & $(0.00377)$ & $(0.00282)$ & $(0.00409)$ & $(0.00779)$ \\
\hline R-squared & 0.408 & 0.619 & 0.604 & 0.180 \\
\hline
\end{tabular}

Table 10a: First Stage Regressions at the 'département' level

\begin{tabular}{|c|c|c|c|c|c|}
\hline & Filing rate & Worker Lawyer rate & Conciliation rate & Trial rate & $\begin{array}{c}\text { Worker Winning } \\
\text { rate }\end{array}$ \\
\hline Lawyers & $\begin{array}{l}-12.44 \\
(8.828)\end{array}$ & $\begin{array}{c}19.04 * * * \\
(4.002)\end{array}$ & $\begin{array}{c}18.02 * * * \\
(3.700)\end{array}$ & $\begin{array}{c}-11.05^{* *} \\
(4.700)\end{array}$ & $\begin{array}{l}-2.230 \\
(4.225)\end{array}$ \\
\hline R-squared & 0.535 & 0.377 & 0.274 & 0.249 & 0.174 \\
\hline $\begin{array}{l}\text { F-test of joint } \\
\text { sgnificance }\end{array}$ & 1.990 & 22.67 & 23.75 & 5.532 & 0.279 \\
\hline
\end{tabular}




\begin{tabular}{|c|c|c|c|c|}
\hline & Job Destructions & Job Creations & Net Job Creations & $\begin{array}{l}\text { Dismissed persons } \\
\text { with seniority less } \\
\text { than } 2 \text { years }\end{array}$ \\
\hline Worker Lawyer rate & $\begin{array}{l}-0.225^{*} \\
(0.139)\end{array}$ & $\begin{array}{l}-0.198 * \\
(0.117)\end{array}$ & $\begin{array}{c}0.0273 \\
(0.0948)\end{array}$ & $\begin{array}{l}-0.0364 \\
(0.0442)\end{array}$ \\
\hline $\begin{array}{l}\text { Instruments: Lawyers } \\
\text { R-squared }\end{array}$ & 0.306 & 0.460 & 0.508 & 0.382 \\
\hline Conciliation rate & $\begin{array}{l}-0.235 \\
(0.209)\end{array}$ & $\begin{array}{l}-0.208 \\
(0.167)\end{array}$ & $\begin{array}{l}0.0271 \\
(0.105)\end{array}$ & $\begin{array}{l}-0.00386 \\
(0.0584)\end{array}$ \\
\hline $\begin{array}{l}\text { Instruments: Lawyers } \\
\text { R-squared }\end{array}$ & 0.317 & 0.494 & 0.504 & 0.400 \\
\hline
\end{tabular}




\section{Appendix Tables}

Table A.1: Judicial Indicators and the Business Cycle

\begin{tabular}{|c|c|c|c|c|c|}
\hline & Filing rate & Worker Lawyer rate & Conciliation rate & Trial rate & $\begin{array}{l}\text { Worker Winning } \\
\text { rate }\end{array}$ \\
\hline Unemployment rate & $\begin{array}{c}0.897 * * * \\
(0.108)\end{array}$ & $\begin{array}{c}-0.876^{* * *} \\
(0.0880)\end{array}$ & $\begin{array}{c}1.177^{* * * *} \\
(0.118)\end{array}$ & $\begin{array}{c}-1.435^{* * *} \\
(0.141)\end{array}$ & $\begin{array}{c}-1.353^{* * *} \\
(0.135)\end{array}$ \\
\hline R-squared & 0.038 & 0.046 & 0.056 & 0.093 & 0.076 \\
\hline
\end{tabular}

Table A.2: The Impact of Past Labor Flows on Lawyer, Judge and Staff Densities

\begin{tabular}{lccc}
\hline \hline & Lawyers & Judges & Staff \\
Job Destructions (-1) & -0.0004 & -0.0000 & 0.0000 \\
& $(0.0003)$ & $(0.0000)$ & $(0.0001)$ \\
Job Destructions (-2) & -0.0002 & -0.0000 & -0.0000 \\
& $(0.0002)$ & $(0.0000)$ & $(0.0001)$ \\
R-squared & 0.11 & 0.01 & 0.12 \\
\hline \multirow{2}{*}{ Job Creations (-1) } & Lawyers & Judges & Staff \\
& 0.0001 & -0.0000 & 0.0001 \\
Job Creations (-2) & $(0.0004)$ & $(0.0000)$ & $(0.0001)$ \\
& 0.0006 & 0.0000 & -0.0000 \\
R-squared & $(0.0006)$ & $(0.0000)$ & $(0.0001)$ \\
\hline & 0.11 & 0.00 & 0.12 \\
Net Job Creations (-1) & Lawyers & Judges & Staff \\
& $0.0003^{*}$ & 0.0000 & 0.0000 \\
Net Job Creations (-2) & $(0.0002)$ & $(0.0000)$ & $(0.0001)$ \\
& 0.0005 & 0.0000 & 0.0000 \\
R-squared & $(0.0003)$ & $(0.0000)$ & $(0.0001)$ \\
\hline Observations & 0.11 & 0.00 & 0.12 \\
\hline \hline
\end{tabular}

Robust standard errors are between parentheses. * significant at 10\%; ** significant at $5 \%$, ***significant at $1 \%$. Each regression includes jurisdiction and year fixed effects. 1999 labor force of the jurisdictions is used as weights. Clusters: jurisdiction level. 
Table A.3: (Mis)allocation of Judges by Industry

\begin{tabular}{c|c|c|c|c}
\hline \hline $\begin{array}{l}\text { Dependent variable: Change in the number of judges by section in } \\
2002\end{array}$ & Manufacturing & Trade & Service & All sections \\
\hline Change in the employment in the industry over 1993-2002 & 0.00473 & $-0.0303^{* * *}$ & $-0.0109^{* * *}$ & $-0.0563^{* * *}$ \\
& $(0.0472)$ & $-0,0099$ & $-0,0019$ & $(0.0154)$ \\
R-squared & 0.000 & 0.035 & 0.11 & 0.048 \\
\hline Observations & 264 & 264 & 264 & 264 \\
\hline \hline
\end{tabular}

Notes: Columns (2) (3) and (4) display the regressions of the change in the local number of judges on the change in employment beween 1993 and 2002. Over 1993-2002, the number of judges has been constant at the local level. Standard errors in parentheses. * significant at $10 \%$; ** significant at $5 \%$, $* * *$ significant at $1 \%$.

Table A.4: Summary Statistics: Duration of the Cases (in days)

\begin{tabular}{lcccc}
\hline \hline & Mean & Std. & Min & Max \\
Judicial Indicators: & & & & \\
Time Delay to the Conciliation Stage & 45 & 13 & 18 & 222 \\
Time Delay to the Trial Stage & 176 & 86 & 32 & 543 \\
Total Duration of the Case & 271 & 76 & 95 & 754 \\
\hline \hline
\end{tabular}

Notes: Means of the jurisdition*year indicators, over the 264 jurisdictions and the years 1996-2003. "Time delay to the conciliation stage" is the time it takes to get a conciliation hearing. "Time delay to the trial stage" is the time it takes to get a judgment hearing when the conciliation fails. Total duration of the case is the average duration to the termination of the case whatever the outcome of the judicial process is (trial, conciliation...).

Table A.5: First Stage Regressions: Effect of Legal Inputs on Time Delay to the Conciliation Hearing Dependent Variable: Time Delay to the Conciliation Hearing

\begin{tabular}{lcc} 
Lawyers & $25.47 * * *$ & $25.48^{* * *}$ \\
& $(6.540)$ & $(6.628)$ \\
Staff & & $-57.62^{*}$ \\
& & $(32.02)$ \\
R-squared & 0.08 & 0.09 \\
\hline F-test of joint sgnificance (p-value) & $15.17(0.000)$ & $8.91(0.000)$ \\
\hline \hline Robust standard errors are between parentheses. * significant at 10\%; ** significant at 5\%, ***significant at 1\%. Observations are for 264 \\
jurisdictions and for the years 1996-2003 (2,112 obs.). Each regression includes jurisdiction and year fixed effects, and local business cycle \\
indicators. 1999 labor force of the jurisdictions is used as weights. Clusters: jurisdiction level. F is the F statistic of the joint significance of the \\
variables.
\end{tabular}


Table A.6: Time Delay to the Conciliation Hearing and Job Flows: 2SLS Estimates

\begin{tabular}{lccc}
\hline \hline & Job Destructions & Job Creations & Net Job Creations \\
\hline Time Delay to Conciliation (log) & $-0.245^{* * *}$ & -0.0410 & $0.204^{* *}$ \\
& $(0.0711)$ & $(0.0374)$ & $(0.0872)$ \\
Instruments: Lawyers & 0.18 & 0.441 & 0.378 \\
R-squared & $-0.200^{* * *}$ & -0.0120 & $0.188^{* * *}$ \\
\hline Time Delay to Conciliation (log) & $(0.0552)$ & $(0.0339)$ & $0.0695)$ \\
& 0.34 & 0.19 & 0.72 \\
Test of overidentifying restrictions (p-value) & & & 0.406 \\
Instruments: Lawyers and staff & & 0.456 & 0.116 \\
R-squared & & & $0.4 \%$ \\
\hline \hline
\end{tabular}

Robust standard errors are between parentheses. * significant at 10\%; ** significant at 5\%, ***significant at $1 \%$. Observations are for 264 jurisdictions and for the years 1996-2003 (2,112 obs.). Each regression includes jurisdiction and year fixed effects, and local business cycle indicators. 1999 labor force of the jurisdictions is used as weights. Clusters: jurisdiction level. 